\title{
Aruanne PetserimaA POLIITILISE JA SOTSIAALSE OLUKORRA KOHTA 1927. AASTAL
}

\author{
Ott Koor
}

Petserimaa küsimus on tänaseni üks riikliku järjepidevuse küsimuse olulistest komponentidest. Tartu rahulepinguga läksid varem Pihkva kubermangu kuulunud Petseri piirkonna vallad Eesti Vabariigi haldusalasse ning tsaariaegsed suhted idapoolsete aladega katkesid. Selline murranguline pööre tekitas mõningate kogukondade kiiret vaesumist, mille tõttu ilmnes piirkonnas ridamisi sotsiaalseid probleeme: tööpuudus, alkoholism jne. Seepärast avaldus Petserimaal kahe maailmasõja vahel riigivastaseid meeleolusid, mida nõukogudemeelsed poliitilised jõud enda huvides ära kasutasid. Tõsi, eelkõige esines riigivastaseid hoiakuid Petserimaa idapoolsetes valdades, kus elasid peamiselt vene rahvusest kodanikud, kelle huvid olid Vene sisealadega tihedamalt seotud.

Järgnev aruanne kuulub Siseministeeriumi arhiivifondi (Rahvusarhiiv (edaspidi RA), ERA.14.1.1395) ja selle on koostanud 1927. aastal Poliitilise Politsei abikomissar Nikolai Nuder. ${ }^{1}$ Aruande kirjutamise põhjus oli valitsuse eesmärk taastada iseseisvuse esimestel aastatel tegutsenud Petseri maaülema ametikoht, ${ }^{2}$ teostamaks järelevalvet kohalike institutsioonide üle ning põimimaks Petserimaad tihedamalt Eesti riigiga. ${ }^{3}$ See koostati siseminister Jaan Hünersoni ${ }^{4}$ palvel. Publikatsiooni lõpus on esitatud siin kindlaks tegemata ametniku S. Sommeri kommentaar aruandele. Allika väärtus seisneb selles, et see hõlmab võrdlemisi laiaulatuslikku probleemistikku, peegeldades piirkonnas esinevat poliitiliste ja sotsiaalsete, riiklike ja kogukondlike huvide põrkumist. Lisaks kirjeldatud probleemidele pakutakse aruandes võimalikke lahendusi, esitamata siiski konkreetsemaid tegevusplaane. Dokumendi rõhuasetus on eelkõige Petseri maakonna idapoolsetel aladel, mis näitab selle regiooni nõrgemat sidusust Eesti aladega.

\footnotetext{
1 Mai Krikk, Eesti poliitiline politsei 1920-1940 (Tallinn: Olion, 2002), 227.

2 Petseri maaülema institutsioon tegutses aastatel 1920-21 eesmärgiga siduda piirkond tihedamalt ülejäänud Eestiga. Maälema materjale säilitatakse arhiivifondis RA, ERA.13. 3 "Maaülem Petserimaale", Päevaleht, 05.01.1927, 4.

4 Jaan Hünerson (1882-1942) - siseminister Jaan Teemanti kolmandas valitsuses (04.03.1927-09.12.1927) ning Jaan Tõnissoni kolmandas valitsuses (09.12.1927-04.12.1928).
} 


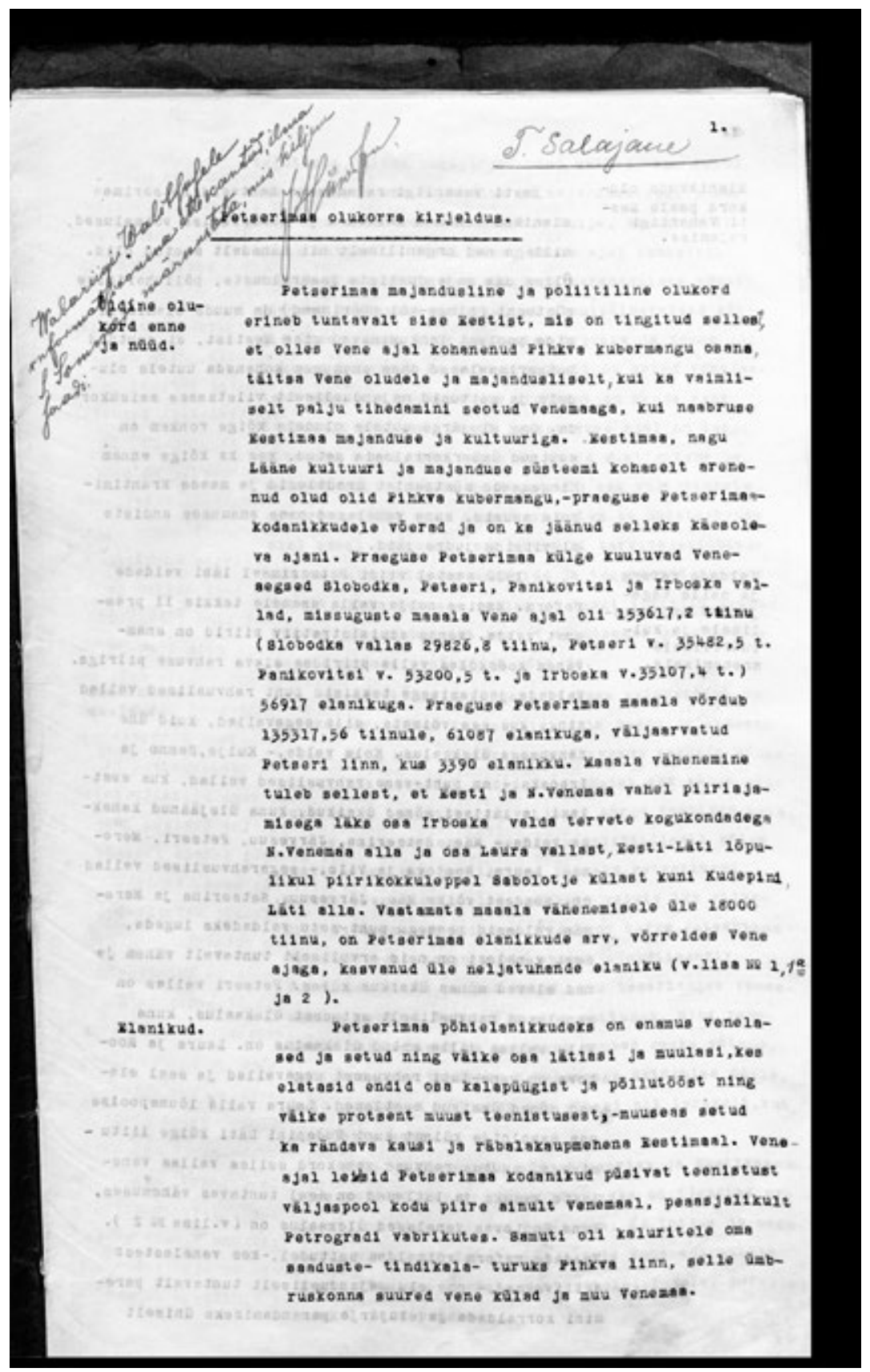

Joonis 1. Aruande esimene leht. RA, ERA.14.1.1395, 1. 4 
Selliseid meeleoluraporteid on esimesest iseseisvusperioodist säilinud võrdlemisi vähe. Enamik sarnastest dokumentidest kuulusid arvatavasti Poliitilise Politsei materjalide hulka, mis hävitati enne Nõukogude võimu kehtestamist 1940. aastal.

Lisaks poliitilisele ja sotsiaalsele küljele suunab allikas tähelepanu ka inimesele ja muutuvale keskkonnale tema ümber. Antud juhul põimuvad rahvastiku kiire kasv ja Pihkva järve äärsete alade soostumise küsimused, mille tõttu inimeste eluruum maa-alal vähenes. Petserimaa oli esimesel iseseisvusperioodil üks tihedamalt asustatud piirkondi, kus ruutkilomeetril elas keskmiselt rohkem kui 20 inimest. ${ }^{5}$ Maakondade lõikes oli Petserimaa rahvastiku taastootmine Eestis kiireim. 1934. aasta andmete järgi oli o-9-aastaste inimeste osakaal maakonnas $24,8 \%$ ning 10-19-aastaste osakaal $19,5 \% .^{6}$

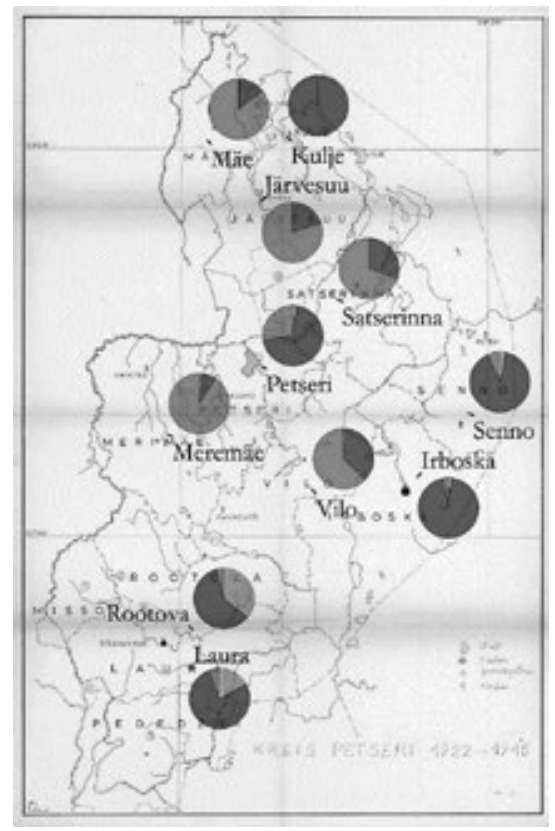

Joonis 2. Petserimaa valdade rahvuslik koosseis. Tumedama halliga on märgitud venelased, sinakashalliga eestlased ning helehalliga muud rahvused, kellest enamiku moodustavad lätlased. Kaardi aluseks on RA, EAA.5355.1.428

Allikapublikatsioonis on teksti arusaadavuse eesmärgil küll veidi kohandatud aruande keelekasutust ja kirjapilti, kuid konarlikus lausestuses olulisemaid muudatusi tehtud ei ole. Lisaks on allakriipsutusega märgitud tekstis leiduvad siseministri allajoonimised. Originaalis on tekst masinkirjas. Käsikirjalised märkused on esitatud kursiivis. Erisusi on tehtud dokumendi küljenduses: kui originaalis on alapealkirjad joondatud vasakule ja tekst paremale, siis publikatsioonis on alapealkiri joondatud nagu tekstki. Muudetud on dokumendis leiduvate tabelite struktuuri, koondades sarnased andmed ühte tabelisse. Isikute kohta käiv joonealuste märkustena

\footnotetext{
5 "Eesti rahvastik 1934", Eesti ajaloo atlas (Tallinn: Avita, 2006), 110.

6 "Rahvastiku vanuslik koosseis admin.-üksuste järgi", Eesti arvudes 1920-1935 = Estonie en chiffres: résumé rétrospectif de 1920-1935 (Tallinn: Riigi Statistika Keskbüroo, 1937), 10.
} 
esinev lisateave pärineb Rahvusarhiivi isikuandmete kartoteegist. Kõik pindalaühikud on esitatud tiinudes. ${ }^{7}$ Publikatsioonist on välja jäetud andmed Petserimaa kohta 1913. aastal ning kirjeldused maakonna teede kohta. Ülevaate saamiseks Petserimaa valdade rahvuslikust koosseisust on kaardile (joonis 2) kantud allikas leiduv andmestik rahvastiku kohta. ${ }^{8}$

$7 \quad 1$ dessa(tiin) $=10925,4 \mathrm{~m}^{2}$.

8 RA, EAA.5355.1.428: "Petserimaa kaardid ja skeemid". Aluskaardile on märgitud ka Misso vald, mis kuulus Võru maakonda, ning Pededze vald, mis asus Läti riigi territooriumil. 


\section{PETSERIMAA OLUKORRA KIRJELDUS}

VABARIIGI VALITSUSELE INFORMATSIOONINA ETTE KANTUD, ILMA S. SOMMERI MÄrKUSTETA, MIS HILJEM SAADI

\section{Üldine olukord enne ja nü̈̈d}

Petserimaa majanduslik ja poliitiline olukord erineb tuntavalt Sise-Eestist, mis on tingitud sellest, et olles Vene ajal kohanenud Pihkva kubermangu osana, täitsa Vene oludele ja majanduslikult kui ka vaimselt, palju tihedamini seotud Venemaaga kui naabruse Eestimaa majanduse ja kultuuriga. Eestimaa, nagu Lääne kultuuri ja majanduse süsteemi kohaselt arenenud olud olid Pihkva kubermangu, praeguse Petserimaa kodanikkudele võõrad ja on ka jäänud selleks käesoleva ajani. Praeguse Petserimaa külge kuuluvad Vene-aegsed Slobodka, Petseri, Panikovitski ja Irboska vallad, missuguste maa-ala Vene ajal oli 153617,2 tiinu (Slobodka vallas 29826,8 tiinu, Petseri v. 35482,5 t., Panikovitsi v. 53200,5 t. ja Irboska v. 35107,4 t.). Praeguse Petserimaa maa-ala võrdub 135417,56 tiinule, 61087 elanikuga, välja arvatud Petseri linn, kus 3390 elanikku. Maa-ala vähenemine tuleb sellest, et Eesti ja N. Venemaa vahel piiriajamisega läks osa Irboska valda tervete kogukondadega N. Venemaa alla ja osa Laura vallast, Eesti-Läti lõplikul piirikokkuleppel Sabolotje külast kuni Kudepini Läti alla. Vaatamata maaala vähenemisele üle 18000 tiinu, on Petserimaa elanikkude arv, võrreldes Vene ajaga, kasvanud üle nelja tuhande elaniku.

\section{Elanikud}

Petserimaa põhielanikkudeks on enamus venelased ja setud ning väike osa lätlasi ja muulasi, kes elatasid endid osa kalapüügist ja põllutööst ning väike protsent muust teenistusest; muuseas setud ka rändavad kausi- ja räbalakaupmeestena Eestimaal. Vene ajal leidsid Petserimaa kodanikud püsivat teenistust väljaspool kodu piire ainult Venemaal, peaasjalikult Petrogradi vabrikutes. Samuti oli kaluritele oma saaduste - tindikala turuks Pihkva linn, selle ümbruskonna suured vene külad ja muu Venemaa. 


\section{Elanikkude olukord pärast Eesti Vabariigi rajamist}

Eesti Vabariigi rajamisega kaotasid Petserimaa elanikud Venemaa kalaturu ja tööleidmise võimalused, millega nad orgaaniliselt nii lähedalt seotud olid. Olles oma majanduslike iseärasuste, põlluharimise süsteemi (hingevõi nöörimaad) ${ }^{9}$ ja muude elamisviiside poolest lahkuminevad Sise-Eestist, ei suutnud petserimaalased oma enamuses kohaneda uutele oludele ja sattusid majanduslikult viletsasse seisukorda. Oma elujärge uutele oludele kõige rohkem on suutnud ümber korraldada setud, kes ka kõige ennem hingemaade süsteemist ära ütlesid ja maade kruntimisele asusid, kuna venelased omas enamuses endiste eluviiside juurde jäid.

\section{Valdade reform ja selle tagajärjed majanduslikele ja kultuursetele arenemistele}

1922. aastal viidi Petserimaal läbi valdade reform. Endise nelja valla asemele tekkis 11 praegust valda. Nende administratiivpiirid on enam-vähem kooskõlas valla piirides elava rahvuse piiriga. Valdade jaotumisega tekkisid puht rahvuslikud vallad ning kus see võimatu, siis segavallad, kuid ühe rahvuse ülekaalus. Kolm valda, Kulje, Senno ja Irboska, on puht vene rahvusega vallad, kus eestlasi ja lätlasi mõned üksikud, kuna ülejäänud kaheksa valda, Mäe, Satserinna, Järvesuu, Petseri, Meremäe, Laura, Rootova ja Vilo, segarahvuselised vallad on. Nendest võiks Mäe, Järvesuu, Satserinna ja Meremäe valdasid peaaegu puht setu valdadeks lugeda, sest venelasi on neis arvuliselt tuntavalt vähem ja nad elavad mõnes üksikus külas. Petseri vallas on venelased rahvuselt setudest ülekaalus, kuna Vilo vallas jälle setud ülekaalus on. Laura ja Rootova on vene-läti rahvusest segavallad ja seal elavad mõned üksikud eestlased. Laura valla lõunapoolse osa Sabolotje külast kuni Kudepini Läti külge liitumisega muutus rahvuse vahekord selles vallas venelaste kasuks ja lätlased on seal tuntavas vähemuses, kuna Rootovas venelased ülekaalus on. Valdade reform võimaldas setudel, kes venelastest aktiivsemad, oma elu majanduslikult tuntavalt paremini korraldada ja elujärje parandamiseks ühiselt tegutseda, mille tagajärjel need vallad, kus setud, kas enamuses või ülekaalus on, majanduslikult puht vene valdadest, Kulje, Senno ja Irboska vallast, Eesti iseseisvuse ajal tuntavalt rohkem arenenud ja oma elujärje parandamises edasi jõudnud vaatamata sellele, et elamistingimused kõigil ühesugused, kuna põllupind Irboska ja

$9 \quad$ Maa kuulus juriidiliselt valdavalt külakogukondadele, mida hariti perekonniti pikkade kitsaste ribadena. 
Senno põllumast halvem. Ka kultuuriliselt on setud venelastest ees, kirjaoskamatuse protsent on nende seas tuntavalt väiksem. Eesti iseseisvuse ajal on isegi võrsunud noori, kes tunnevad end eestlastena ja püüavad selles sihis ka tegutseda ehk küll viimaste arv veel väike on. Samuti on setud ka ühistegevuse alal edasi sammunud, nii mitmedki tarvitajate ühisused on setu valdades asutatud ja tegutsevad rahuldavalt, kuna Meremäe vallas on isegi korralik piimaühisus juba mitmendat aastat tegutsemas ja põllupidajate setude poolehoidu võitnud.

\section{Elanikkude meelsus}

Majanduslikult kõige viletsamas seisukorras on Pihkva järve äärne Kulje vald, siis Senno ja Irboska vallad ning Mäe, Satserinna ja Järvesuu valdade mõned külad, kes elatavad endid kalapüügist või kelle põlluharimist takistab Pihkva järve kõrge veepinna seis. Nendes valdades on ka meeleolu poliitiliselt kõige eestivaenulikum ja elanikud näeksid Petserimaad N. Vene osana heal meelel, oleksid valmis iga silmapilk N. Venemaaga ühinema. Üldse on terve Petserimaa vene rahvusest kodanikkude enamus sümpatiseeriv N. Venemaale. Ka paljud setud, kes tsaariaegse venestamise hooajal Vene mõju alla sattunud, ning venelaste rahvuslikud ja usulised kombed omaks võtnud, kalduvad oma vaadetes $\mathrm{N}$. Venemaaga ühinemise poole, kuid nendes ei väljendu see siiski nii teravalt, kui venelaste seas.

Selle, N. Venemaale sümpatiseeriva ja eestivaenuliku poliitilise meelsuse põhjuseks on:

1. Endine orgaaniline tihe siduvus Venemaaga

2. Loidus ja oskamatus Venemaast lahutamise järele kohaneda uutele, Eesti riikluse korrale vastavatele oludele

3. Kalurite kalaturu puudus

4. Teenistuse- ja tööpuudus

5. Rahvuslik ning veresugulus Venemaaga

6. Meie senine piiripoliitika

7. Kihutustöö N. Vene piirivõimude kui ka Petserimaal elutseva kahtlase elemendi poolt

8. Üldine majanduslik kitsikus

\section{Kalurid, nende olukord enne ja nüüd}

Petserimaa kalurid, kes osutusid tsaarivalitsuse ajal üheks jõukamaks rahvakihiks, mida kujukalt näitavad Sise-Petserimaast võrdlemisi paremad 
ja eeskujulikumad ehitused, arvurikkad tindikala kuivatusahjud (missugused praegu enamuses lagunenud) ja elumajade sisseseade kõdunenud jäänused, on nüüd, kalaturu kaotamisega, sattunud äärmiselt viletsasse olukorda, nende majandus on miinimumini langenud: majad kokku varisemas, kalapüügiriistad enamuses lõplikult kõdunenud, kalurid ise poolnäljas ja käivad räbalates, enamus perekondi ilma tarvilise toidutagavarata, kus toiduks ainult kalaleem ja kuude kaupa pole leiba nähtudki, mis ajanud need kodanikud meeleheitele. Ainukest pääseteed näevad nad N. Venemaaga ühinemises. Omas viletsuses süüdistavad nad peaasjalikult Eesti Vabariiki põhjendades, et selle tekkimisega on ära lõigatud Vene rikkalik kalaturg. Ülistatakse endiseid aegu, kus üksikud jõukamad kalurid teenisid püügihooajal sadade rublade viisi nädalas, elasid igatpidi külluses, suutsid anda teenistust sadadele kehvematelegi kaluritele, kuna nüüd on nad langenud kerjuse astmeni.

\section{Tindikala ja selle turg}

Tulusamaks sissetuleku allikaks on kaluritele alati olnud tindikala, millele oli rikkalik turg Venemaal. Et Eestis tindikala tarvitajaid vähe, siis on selle hind äärmuseni alla surutud ja puudub täiesti võimalus püüki hooajal realiseerida. Oma seisukorra parandamiseks on kalurid püüdnud iseseisvalt kui ka valitsusasutuste kaudu, tindikalale turgu leida. Selleks on asutatud kalameeste ühingud, kes saatkondi tindikalale turu leidmiseks $\mathrm{N}$. Venemaale saatnud, sidet turu leidmiseks Tallinna N. Vene saatkonnaga otsinud jne.; need püüded on ainult osaliselt rahuldust leidnud. Püsivat tindikala turgu pole meie kalurid N. Venemaal suutnud leida vaatamata tindikala hinnavahe peale meil ja N. Venemaal. Viimaste teadete järele on $\mathrm{N}$. Venemaal, piiri ääres, tindikala hind toorelt kuni 250 marka ja kuivatatul kuni 1100 marka puud, kuna turul see tuntavalt kõrgem on. Meie kalurid võiksid koha peal suuremal arvul mõlemaid sortimente tuntavalt odavamalt realiseerida ja saaksid selle juures võrdlemisi rahulolevalt ära elada.

\section{$N$. Vene vaated meie tindikalale turu leidmisel $N$. Venes}

$\mathrm{N}$. Vene võimude poolt seatakse meie tindikala ostmist poliitikaga ühendusse, mida kalaturu otsijatele mõista antud N. Vene saatkonnas Tallinnas, kui ka kohaliste N. Vene agentide poolt. 1925 a. kevadel, peale Tallinnas ära peetud kalameeste kongressi, on käinud Petserimaa kalurite esitajad, 
eesotsas Riigikogu liikme Vassili Grigorjevi ${ }^{10}$ ja Ivan Voliniga, kalaturu leidmise asjus Tallinna N. Vene saatkonnas, missugune käik aga tagajärgi ei andnud. N. Vene saatkonnas on kalurite esitajaile avalikult mõista antud, et Moskva kõrgem valitsus vaatab kalurite peale rohkem poliitilisest seisukohast. See vaade või poliitika on maksev Moskva poolt käesoleva ajani. Sama on rääkinud 1926 a. suvel oma salajastel Eestis käikudel Pihkva järveäärsetele kaluritele ka 1925. a. kevadel salaja N. Venemaale põgenenud Kulje valla Kamenka küla kodanik Ivan Matvei p. Volin, kes tegutses N. Venemaa kasuks salakuulajana ja seadnud kaluritele tingimiseks, et ainult siis leiab tindikala N. Venemaal turgu, kui kalurid toetavad N. Vene püüdeid, koonduvad riigivastasesse organisatsioonidesse ja tegutsevad salakuulamise alal. Need N. Vene võimude ja üksikute agentide vaated kalaturu leidmise asjus on väga hästi teada ka meie kaluritele.

\section{Kalurite ühingud ja nende senine tegevus}

Parandust kalurite seisukorda ei suutnud tuua ka 1920. a. organiseeritud ja käesoleva ajani tegutsevad Pihkva järveäärsed kalameeste ühingud. Nende ühingute etteotsa poetasid endid mitte ausad ja omakasu püüdjad isikud, kelledest paljud eestivaenulikud ja ei tegutsenud kalurite kui ka Eesti riiklikes huvides. Nende poolt koondati kalameeste ühingute ümber oma mõtteosalised, et leida toetust neilt oma plaanide läbiviimisel. Nimetatud kalameeste ühingud, kuhu etteotsa kuulusid endine Petseri maavalitsuse esimees Dmitri Beresin, ${ }^{11}$ Ivan Volin, preester Valentin Smirnov, ${ }^{12}$ Ivan

\footnotetext{
$10 \quad$ Vassili Grigorjev, Grigori p. (snd 11.03.1870) - Riigikogu liige, kes soovitas Eesti Vabariigi vene rahvusest kodanikele Petserimaa Nõukogude Venemaa külge liitmist, mis pidavat Grigorjevi sõnul toimuma ühel sügisööl.

11 Dmitri Beresin, Maksimi p. (snd 22.11.1892) - elas Järvesuu vallas Gorodištše (Linnaste) külas. Käis tihedalt läbi Nõukogude Liidu salakuulaja Ivan Voliniga. 1923. aastal olid tal kokkusaamised Nõukogude Liidu agendi Grigori Tšubajeviga, kellelt sai tasu müüdud kalavõrkude eest. Pärast Volini põgenemist Nõukogude Liitu jäi temaga kirjavahetusse. Oli heas vahekorras ja läbisaamises salakuulajate punkti pidaja preester Valentin Smirnoviga Lisje külast. 1927. aastal süüdistati Beresinit riigivastases tegevuses, sest ta levitas avalikult ärevust tekitavaid laimavaid kuulujutte riigiasutuste ja ametkondade tegevuse kohta eesmärgiga ärgitada riigivastaseid meeleolusid kohaliku elanikkonna seas. Ta mõisteti kaheksaks kuuks kindlustusvangistusse. Lisaks keelati tal viibimine piirkondades, kus kehtis kaitseseisukord, sealhulgas Nõukogude Liidu piiri äärsetel territooriumitel.

12 Valentin Smirnov, Niili p. (snd 1886) - elas Kulje vallas. Apostliku õigeusu preester, kes oli seotud Riigikogu liikme Vassili Grigorjevi ja Nõukogude Liidu salakuulaja Ivan Volini tegevusega.
} 
Birjukov, ${ }^{13}$ Timofei Morzevitski ${ }^{14}$ ja teised, kes kõik riigivastasest tegevusest osa võtsid, said kalameeste olukorra parandamiseks valitsusest laenu. Seda laenu ei antud otsekohe tegelikele kaluritele, vaid jagati kalameeste ühingutes juhtivat osa etendajate ja nende mõtteosaliste isiklisteks tarvidusteks, tarvitades selleks igasuguseid kombinatsioone. Nii liiguvad järveäärsete kalurite seas kuuldused, et kirjaoskamatuilt kaluritelt on võetud allkirju suuremate toetussummade peale, kui nendele tegelikult raha välja antud. Ka tuli nendes ühingutes avalikke rahakõrvaldamisi juhtivate isikute poolt ette, missugune asi on kohtuvõimude lahendada. Kalaturu leidmiseks ei astunud ühingud õieti mingit tõsist sammu, otsisid sidet ainult N. Venemaaga, teades seejuures väga hästi $\mathrm{N}$. Vene poliitilisi tingimusi kalaturu leidmisel, kuna Lätis, Leedus ja Poolas turu leidmiseks katseidki ei tehtud.

\section{Kala tarvitamise ja turu leidmise kavad. "Keskkala" ja vaheltkauplejad. Ühistegevuse õhutamine}

Et praeguse N. Vene kaubanduspoliitika tõttu puudub lootus N. Venemaal tindikalale turgu leida, peaks vastavad organid muid tindikala kasutamise võimalusi otsima ja ka leidma, kas kuidagi loomatoiduks tarvitamise, mõneks tulutoovaks väetisaineks ümbertöötamise või muul näol. Peaks rohkem sisemaal tindikalade tarvitamist propageerima, tindikala tarvitama suuremal arvul toiduainena vangimajades ja sõjaväes; püüda turgu leida väljaspool N. Venemaad: Poolas, Leedus ja Lätis, samuti otsida võimalusi nende Vene turule saatmiseks. Kord oli ajalehes märkus, nagu saaks tindikalast hea kvaliteediga seepi, ka seda peaks järele uurima ja katseid tegema. Kalurite olukorra parandamiseks tuleks ka paremini organiseerida suurkalade müüki, mis võimaldaks kaluritel ilma vaheltkauplejateta

$13 \quad$ Ivan Birjukov, Jevdokimi p. (snd 22.04.1883) - elas Järvesuu vallas Gorodištše (Linnaste) külas. Juba 1919. aastal oli tal tihedam läbikäimine Nõukogude Venemaa salakuulaja Ivan Voliniga, kellelt sai riigivastase tegevuse eest rahalist kasu. Politseiasutustele oli Birjukov tuntud Eesti Vabariigi vastase tegelasena. Teda süüdistati riigivastase organisatsiooni tegevusest osavõtmises, sest politsei andmetel 1926. aastal tegutses Tartus ja Petserimaal paljastatud kommunistlikus salaorganisatsioonis, kuid puudulike süüdistusmaterjalide pärast vastutusele ei võetud.

14 Timofei Morzhevitski, Antoni p. (snd 21.01.1880) - elas Kulje vallas Seltsõi-Väike külas. Võttis osa Ivan Volini riigivastase organisatsiooni tegevusest, olles sidepidajaks teiste organisatsiooni liikmetega. Volini ülesandel tegi ta sõite Tallinnasse ja Tartusse, vahendades informatsiooni seal asuvatele salakuulajatele. Sealhulgas organiseeris ta kokkusaamisi Voliniga Saatserinna vallas Sahodõ külas. Talle määrati riigivastase tegevuse eest 1927. aastal kahe aasta pikkune paranduslik töö koostöö eest Nõukogude Liidu agentidega. Enne tähtaega vahi alt vabastatud, asus ta elama Kulje valda Petserimaal. Käis läbi Valentin Smirnoviga. 
võimalikult õiglasema tasu eest suurkalu realiseerida. Praegu sünnib suurkalade müük siseturule "Keskkala" ja kohalikkudele ülesotsijate kaudu. Viimastel aastatel, mil "Keskkala" edasi müüvad või jälle sisemaale edasi toimetavad, näevad "Keskkalas" enestele võistlejat, püüavad viimase tegevust koha peal halvata ja kala ülesostus jämedat otsa enese kätte kiskuda. ${ }^{15}$ Vaheltkauplejatega edukamaks võistlemiseks ja kalahinna tõstmiseks oleks soovitatav "Keskkala" poolt avada otsekohe järve äärde ülesostu punktid, nende juurde ehitada jääkeldrid, mis võimaldaksid kalapüüki ja saagi alleshoidmist suve ajal. Sarnased jääkeldrid on praegu Kulje vallas Lisje ja Sabolotje külades ja kalurid tõendavad nende kasulikkust; kuuldub ainult nurinat, et ei ole mitte kõigile kättesaadavad ja väga kaugel mõnest rajoonist. Kala edukamaks turule toimetamiseks tuleks korraldada kindlaid reise vastavate veoabinõudega ülesostupunktide ja turgude (Tartu) vahel. Selleks asutada püügi ja saagirikkamatesse piirkondadesse väiksemaid sadamaid, kus võiksid peatada kalaveo laevad. Need sadamad tuleks asutada jääkeldrite asukohtade juurde; tuleks leida võimalust kalade eksportimiseks ka välisturule, mille oma peale peaks võtma "Keskkala" või E.T.K., ${ }^{16}$ kes avaks järve äärde omad haruühisused. Nende ühisuste hooleks olgu ka kalurite vastukaupadega varustamine, ühistegevuse tunde õhutamine, kalameeste ühingute asutamine, nende ümber liikmete koondamine ja praeguste ühingute reorganiseerimine. Peale kalasaaduste peaksid need "Keskkala" või ETK haruühisused üles ostma ka aiasaadusi, mune jne., mis oleks ergutuseks nende alade edendamisele. Sama ühisuste juhatajate kohuseks olgu ka kalameestele nõuandmisega abiks olla igal alal, et kodanikkude ühistegevuse huvi äratada ja neid ühisuste ümber koondada. Siinjuures peaks aga kindlasti silmas pidama, et ühistegevus põhineks ka puht ühistegelisel alusel, millest kõrvalekaldumisi ei oleks; esialgne vähene poolehoid ühistegevusele ei tohiks pettumusi tuua, sest venelased on iga uuenduse vastu niikuinii umbusklikud. Teiseks kala edukaks minekuks on tema hind turul. Praegu on Petseri turul kala küllaldaselt saada, kuid tarvitajad peavad selle hinda liiga kõrgeks ja paljudele käib selle muretsemine üle jõu; liha tarvitamist peetakse odavamaks. Kalahindade alandamine on võimalik ainult saagi viljakuse tõstmise ja püsiva ning kindla turu leidmise tagajärjel. Saagi viljakuse tõstmiseks peaks kaluritele toetust

\footnotetext{
15 Eesti Kalameeste Ühisuse Keskliit “Keskkala” tegeles lisaks edasimüügile ka kohalike kalameeste materiaalse toetamisega. 1925. aastal anti Pihkva järve ühisuste töötutele kalameestele kokku üle 800 ooo marga toetusi. Vt RA, ERA.2000.1.1261.

16 Eesti Tarvitajateühisuste Keskühisus - tegutses aastatel 1917-44. Materjale säilitatakse arhiivifondis ERA.R-115.
} 
andma laenude abil püügiriistade muretsemiseks või jälle otsekohe vastavaid püügiriistu pikaajalise krediidi peale, missugust operatsiooni väga hästi võiks toimida "Keskkala" või ETK valitsuse krediitide toetusel.

\section{Kalurite nurinad Pihkva järve veepiiri üle}

Kuuldub nurinaid kalurite seas Pihkva järvel ka piiri kohta, mis on Eestipoolse kalda ligidal. Piiriga on lõigatud kalarikkad kohad N. Venemaa külge ja suurkalade püük sünnib peaasjalikult sealpool piiri, kuhu tihti meie kalurid vargsi lähevad, kus nad tihti $\mathrm{N}$. Vene piirivalve võimude poolt tabatakse. Ka siin ei jäta N. Vene võimud juhust kasutamata kihutustööks kalurite seas eestivaenuliku meeleolu loomiseks näidates, et kalurite viletsuses on süüdi piir. Oles soovitatav võimaldada, kokkuleppe teel $N$. Venemaaga, meie kaluritele ka üle piirijoone kalapüüki Pihkva järvel andes vastavaid soodustusi N. Vene kaluritele Peipsi järvel.

\section{Kalasaaduste sisemaale saatmist takistav teede puudus Sise- Petserimaa ja ranna vahel}

Kalaturule toimetamist ligemasse piirkonda - Järvesuu valda ja sellega piirduvasse Võru maakonda. Raskendab ka teede puhtus, mis võimaldaks otsekohest väljapääsu hobusel Kulje valla järveäärsetest küladest, sest Kulje valda eraldab Järvesuu ja teistest valdadest läbipääsuta soo. See teede puudus mõjub halvavalt kalahinnale, ei suudeta kala tarvitajatele igal pool kättesaadavaks teha, mille tõttu kala eest täit hinda ei saa. Teede ja ka hobuste puudusel käivad kalurid tihti jala rannast eemal asuvates külades kalu müümas oma saaki seljas kandes. Sagedasti vahetatakse kalad leivavilja ja jahu vastu, mis samuti seljas koju kantakse. Niisugune müügiviis on aegaraiskav ja kaasa võetud vähese kalade arvu tõttu ei tasu ennast ära. Hobusega pääseb praegu Kulje valla küladest Järvesuu valda ja Petseri ainult Kulje küla kaudu suurt ringi tehes, kuna sama valla Lisje, Budovitsi ja nendest lõuna pool asuvatest küladest suvel üldse hobusega välja ei pääse. Kergemaks väljapääsuks Kulje valla järveäärsetest küladest Järvesuu ja teistesse valdadesse tuleks luua maantee ühendus nende vahel. Petseri maavalitsusel olla mingisugune projekt Krasnaja Gora ühendamiseks Järvesuu valla Kuliska külaga, mis tuleks ka ellu viia. Suve ajal peavad Kulje valla kodanikud ühendust Petseriga ja muu Petserimaa osaga ainult paatide abil. Nimetatud tee ehitamine hõlbustaks tuntavalt läbikäimist järveäärse rajooni ja Sise-Eesti vahel ja 
annaks ühtlasi kohalikele elanikele teenistust, saades sellega üheks otstarbekohasemaks vahendiks hädaabitöödel. Selle tee lõplik siht Krasnaja Gora ja Sise-Petserimaaga jäägu asjatundjate otsustada. Nimetatud teega võiks harutee kaudu ühendada veel Lisje ja teisi külasid.

\section{Pihkva järve veepinna kõrge seis, selle halvav mõju ja veepinna alandamise tagajärjed. Kalda kindlustamine}

Kõige mõjuvamaks abinõuks kalurite seisukorra parandamiseks oleks Pihkva ja Peipsi järvede veepinna alandamine, mille tagajärjel vabaneksid liigvee alt järveäärsed heinamaad ja nurmed ning sood muutuks kuivemaks. Teataval mõõdul Peipsi ja Pihkva järvede veepinna alandamine mõjub tuntavalt ka rannast kaugemale põllumaade peale, sest praegused Mäe, Kulje, Järvesuu ja Satserinna valdade soostunud kohad ja liigvesi on tingitud peaasjalikult Pihkva järve veepinna kõrgusest. Vanemate inimeste seletuse järele on varem Pihkva järve veepind tuntavalt madalam olnud ja siis on praegused soostunud kohad osalt põllu- ja heinamaa all seisnud. Vanemate kalurite seletuse järele tõusta veepind järves aeglaselt, kuid järjekindlalt. See on isegi Eesti iseseisvuse aja kestvusel juba märgata olnud. 1920 ja 1921 a. võis kuiva jalaga Kulje vallast Rositsa külast Satserinna valda Sahodõi külla tulla, siis oli heinamaa veel niivõrd kuiv ja kõva, kuid nüüd on see osa niivõrd soostunud, et läbikäik täiesti võimatu. Varem on järveäärsed heinamaad head ja väärtuslikku saaki andnud, kuid viimased aastad on saagi, kui ka selle väärtuse poolest kehvad. Vihmarikastel suvedel niidetakse hein vees ja veetakse randa kuivatamiseks. Pihkva järve veepinna alandamisega saaks asuda soostunud heinamaade ja soode kuivatamisele ja kultiveerimisele, kaoks kalda uhtumise hädaoht ja langeks iseenesest ära selle kindlustamise vajadus. Kalda kindlustamine kavatsetaval viisil ja ilma järvepinna alandamiseta,- annaks vaevalt soovitavaid tagajärgi. Pealegi oleks see väga kulurikas ja nõuaks palju aega, kuna järvepinna alalise tõusu tõttu uhtumisprotsess edasi kestaks. Kaldakindlustusi võiks või ette võtta hädaabitöödena mõnes Senno, Satserina, Kulje, Järvesuu ja Mäe valla rannaäärsetes külades, kuna kõige selle suure ettevõtte lõplik otsustamine tuleks asjatundjate poolt koha peal läbi viia.

\section{Aianduse edendamine kalurite seas}

Kalurite majanduslikku olukorda aitaks tuntavalt parandada aiandus, mis kõrvalteenistusena neile head sissetulekut võiks anda. Aianduse 
hõlbustamiseks tuleks selleks vähegi kõlbuliku maa-alaga külamaad kruntidesse planeerida. Aiasaadustena on alati nõutavad sibulad, kurgid ja aiamaasikad; nende saaduste turule toimetamist tuleks hõlbustada ja korraldada ilma vahelt kauplejateta. Juba Vene ajast kasvatatakse rannaäärsete kalurite poolt hea eduga kurke ja sibulaid, kuid halva müügikorralduse juures langeb lõviosa teenistusest vahelt kauplejate taskusse. Peaks katsuma neid saadusi ka välisturgudele eksportida, sest müügihooajal on kurkide ja sibulate hind Petserimaal liiga madal, mida igasugused kohalikud kui ka sisemaalt tulnud ülesostjad rohkem alla suruda püüavad. Aianduse edendamiseks tuleks kalureid sellele alale igat pidi ergutada, nende oskusi aianduses süvendada, milleks vastavaid kursusi korraldada ja veel parem, mõni eeskujulik majapidamine sel alal sisse seada. Aianduse tulukuse näitena võiks tuua möödunud suve, kus üksinda Kulje küla miljon marga ümber kurke ära müüdud, mis keskmiselt perekonna kohta üle 10000 marga teeb.

\section{Maa vähesus ja rahvaarvu tihedus kalurite rajoonile. Rahvaarvu vähendamise kavad}

Üheks majandusliku kitsikuse põhjuseks Kulje valla kaluritele on veel elanikkude tihedus ja põllumaa vähesus, sest nimetatud valla maa-ala on umbes 4500 tiinu, millel elab 5560 elanikku, sellega siis alla ühe tiinu elaniku peale, kuhu hulka arvatud ka sood ja kõlbmatud. Loomulik, et sarnast hulka elanikke see väike maa ära elatada ei suuda. Olukorra parandamiseks tuleks rahvaarvu selles rajoonis vähendada ja soodustada, kas sisemaale asumist või koguni võimaldada nende väljarändamist Venemaale. See soodustus võiks olla ühtviisi maksev ka teiste Petserimaa piiriäräre rajooni vene soost kodanikkude kohta, sest mõne tuhande Petserimaa kodaniku kaotamisega, kes pealegi riigivaenulised, ei kaota Eesti riik midagi, küll aga võidab ehk. Kohale jäänud tuleks enam vähem elujõulisteks väikemajapidamisteks koondada, nendele võimalused luua väikemajapidamise ja kalapüügi näol rahuloldavaid sissetulekuid ära elamiseks saada. Ka võiks elanikkude arvu vähendamiseks kalureid sisemaa saartele juhtida, kus selleks ruumi ja neid seal riikliku toetusega kindlustada. Ümberpaigutatavatele tuleb maha jäänud majade ja kruntide eest riigi poolt tasu maksta juhtumisel, kui nad ei saa neid seal ise ära müüa.

Praegu on Kulje valla külades kodanikkude arv, võrreldes küla maaalaga, hulka arvatud ka külale kuuluv kõlbmatu maa järgmine: 


\begin{tabular}{|c|c|c|}
\hline Küla & Elanike arv & Maa suurus \\
\hline Dubka & 236 & 128,30 \\
\hline Sartova & 281 & 212,80 \\
\hline Kolpino & 329 & 48,40 \\
\hline Meedli & 264 & 109 \\
\hline V. Drisliviki & 41 & 14,50 \\
\hline S. Drisliviki & 131 & 69,90 \\
\hline Samosje & 220 & 95,60 \\
\hline Glasovo & 109 & 83 \\
\hline Sabolotje & 275 & 251 \\
\hline Kirsino & 321 & 110,50 \\
\hline Martõsovo & 90 & 96,70 \\
\hline Suhlovo & 145 & 101,20 \\
\hline Dalnevo & 77 & 75 \\
\hline Krasnaja Gora & 251 & 108 \\
\hline Lisje & 921 & 374,30 \\
\hline Budovitsi & 408 & 209,50 \\
\hline Kamenka & 221 & 177,70 \\
\hline Rozitsa & 185 & 100 \\
\hline Meedova & 149 & 35,20 \\
\hline S. Seltsõi & 120 & 30,80 \\
\hline V. Seltsõi & 52 & 30,30 \\
\hline Kulje & 552 & 416,10 \\
\hline
\end{tabular}

Nendest puudub Kamenka, S. Seltsõi ja V. Seltsõi külades aiamaa täiesti ja S. Seltsõi küla asub veest uhutud saarekesel, mis iga aastaga väheneb. Samasugustes majanduslikult viletsates oludes on ka järveäärsed külad Senno, Satserinna ja Mäe valdades.

\section{Senno valla kalurid}

Eriti viletsas seisukorras on Senno valla küladest Anohovo, kus nelja talu kohta puudub maa täiesti. On vähese põllumaaga ja elatavad endid peaasjalikult kalapüügist Kilenets, Sluditsa, Gorbatitsa, Simni Borok, Pesok, Litovizi ja Grivski külad. 


\section{Satserinna valla kalurid}

Satserinna valla küladest on kõige viletsamas seisukorras Issadi küla kodanikud. Need, arvuliselt 78 elanikku, 45 tiinusel liiva saarekesel, elatavad endid ainult kalapüügist. Teistest sama valla küladest on võrdlemisi viletsas seisukorras Sahodõi küla 218 elanikuga 198,70 tiinulisel maa-alal, S. Krupi küla 125 elanikuga 147 tiin. maa-alal ja V. Krupi küla 125 elanikuga 147 tiin. maa-alal ja V. Krupi küla 18 elanikuga 18,30 tiin. maa-alal. Nende peasissetulekuks on kalapüük.

\section{Mäe valla kalurid}

Mäe vallas on eriti viletsas seisukorras Ljubnitsa küla kodanikud, kus on 239 hinge 281 tiinulisel maa-alal ja saavad ülespidamist, peaasjalikult kalapüügist. Peale selle on majanduslikult võrdlemisi viletsas seisukorras:

\begin{tabular}{|l|r|r|}
\hline Küla & Elanike arv & Maa suurus \\
\hline Beresje & 160 & 273,73 \\
\hline Loosina & 116 & 253 \\
\hline S. Rõsna & 305 & 773,92 \\
\hline Andjasaare & 56 & 80,50 \\
\hline Võõbsu $^{17}$ & 352 & 470,42 \\
\hline Pedajaaluse & 41 & 128 \\
\hline Patskirovo & 25 & 5,30 \\
\hline
\end{tabular}

Need külad leiavad, peale kalapüügi, ka põllupidamisest teatud toetust. Põllupidamist takistab aga järve vee kõrge seis, mis kaua püsib. Järvepinna alandamisega väheneks veeseisu kestvuse aeg ja tuleks põllumaad juurde.

\section{Järvesuu valla kalurid}

Järvesuu valla küladest on majanduslikult kõige halvemas seisukorras:

\begin{tabular}{|l|r|r|}
\hline Küla & Elanike arv & Maa suurus \\
\hline Kremesovo & 103 & 183,60 \\
\hline Podmõtsa & 173 & 193,40 \\
\hline Popovitsa & 76 & 122,20 \\
\hline
\end{tabular}

17 Siinkohal on mõeldud Võõbsu (Võõpsu) küla, mis asus soisel alal samanimelisest Võõpsu alevist kagus. 


\begin{tabular}{|l|r|r|}
\hline Küla & Elanike arv & Maa suurus \\
\hline S. Kuliski & 259 & 559,20 \\
\hline V. Kuliski & 99 & 284,50 \\
\hline Gorodistse & 517 & 1062,90 \\
\hline Kesksaare & 31 & 17,10 \\
\hline Tonja & 91 & 234,20 \\
\hline V. Rõsna & 60 & 152,20 \\
\hline Võpolsovo & 119 & 143,60 \\
\hline
\end{tabular}

Need külad saavad ülespidamist, peale kalapüügi, ka põlluharimisest. Peale Gorodistse küla, kannavad teised külad ja ümbrus liigvee all ja maad on soostunud. Järvepinna alandamine tooks ka siin parandust. Majanduslikult eriti kehvas seisukorras on Kremesovo, Podmõtsa, Popovitsa, Gorodistse ja Kesksaare külade elanikud; nende põllumaa on väike ja kehv.

\section{Senno-Irboska piiriäärne rajoon}

Peale Pihkva järveäärse rajooni on olukord õige vilets ja kannatavad kõige rohkem maapuuduse all ka Irboska ja Senno vallad. Nii on Senno vallas 8300 elaniku kohta 6200 tiinu ümber kõlbulikku põllumaad, hulka arvatud ka Halahalnja mõisa maa-ala. Sama on maksev ka Irboska valla kohta, kus 9350 elaniku kohta kõlbulikku põllumaad 6140 tiinu ümber on. Peale selle on mõlemast vallast piiriajamisel N. Vene poole jäänud kokku 1400 tiinu ümber põllu- ja heinamaad. Otstarbekohane väikemaapidamine suudaks Irboska ja Senno valla elanikkudele siiski ära elamist võimaldada, sest nende valdade maa on kõik väga viljakandev ja annab head lõikust. Külameestel puudub oskus oma maalapikest otstarbekohaselt kasutada.

\section{Külamaade kruntidesse planeerimine ja nendele elama asumise soodustamine}

Ka siin peab neid igatpidi ergutama ja õigetele radadele juhatama; majapidamise ja põllumajanduse paremale järjele tõstmiseks kõik külad ligemal ajal kruntidesse planeerida ja omanikkudele kreposteerida. Soodustada planeeritud kruntidele küladest elama asumist, milleks asumislaenu anda hoonete üle viimiseks või ehitamiseks, võimaldada krundile asujal soodsatel tingimustel, ehitusmaterjali saamist. Ehitusmetsa puudusel Petserimaal, ergutada paekivist ehituste püstitamist, pikemaajaliste kõrgemate 
toetussummade, laenu või toetuse saamise eesõiguse või mõnel muul teel. Ehituspaekivi tagavarad on suured ja eriti Senno-Irboska rajoonis ja sellest võiks vähemalt karjalautu ja teisi kõrvalhooneid püstitada. Laenu või toetuse andmise tingimustes ehitusviis kas üldse vabaks jätta, või lubada plaanidest kõrvalekaldumisi; ainult põrandapinna suurusest võiks kinni pidada, mis takistaks majapidamisele mittevastavate ja liiga väikeste hoonete ehitamist.

\section{Kruntide poolitamise hädaoht}

Uute hingemaade kruntide poolitamisele tuleks kiires korras lõpp teha. On harilik nähtus, et tütrele, mehelemineku puhul, eraldatakse isa krundist tiin või rohkem. Sama kaasavara antakse ka järgmistele lastele. Lõpuks tekivad uued maalapikesed, mis kellelegi ära elamist ei võimalda ja tulevikus on neid raske või isegi võimatu kokku koguda. Ka saavad kruntide poolitamisega isegi väheelujõulised majapidamised veelgi elujõuetumaks tehtud ja praegune kulurikas hingemaade kruntimise töö kaotab oma tähtsuse.

\section{Asundustalude planeerimine soo- ja uudismaast}

Põllupinna suurendamiseks tuleb asuda eeskätt uudismaade harimisele, soode kuivatamisele ja kultiveerimisele riigi maatagavarast, milleks head võimalust annavad Belkovo riigisood ja metsad. Kuivatatud riigisoodest ja uudismaast elujõulised asundustalud rajada, kuhu asunikkudeks paigutada sisemaalt riigitruid eestlasi.

\section{Kutseharidus ja kutsekeskkoolid}

Majapidamise oskuse tõstmiseks võiks kutsekoolina asutada igasse valda üks või kaks eeskujulikku talu, keskmise Petserimaa talu suuruses, kus oleks esindatud kõik majapidamise harud sarnases ulatuses nagu see Petserimaa oludele ja nõuetele vastaks. Sarnases majapidamises peaks välja arendama eeskujulikult põlluharimine, karjapidamine, aiandus, mesindus, puukool ja linnukasvatus. Tuleks hoiduda suurtest majapidamistest nagu sisemaal tegutsevad põllutöökoolid, mis tegeliku eluga vastuolus, kuna nendes saadud õpetus on ainult suurtalude kohane ja neid teadmisi kasutada oma koduküla väiketalus ei ole otstarbekas ega ka võimalik. Ülalnimetatud talukoolide loomine peaks sündima kohaste kruntide ära ostmise teel vastavate isikute poolt eramaadest, pikaajalise riikliku krediidi toetusel või antama riigimaa tagavarast teatud soodustusel, mille eest nad siis 
on kohustatud talu vastavalt sisse seadma. Õpetus oleks soovijatele, kelle arv kindlasti piiratud, kuid tasuna õpetuse eest teevad kõik ettetulevad tööd talus ja koolis õpilased. Sarnased koolid/väikemajapidamised peaks suutma kõiki vastavaid nõudeid täita. Ühtlasi oleks nad elavaks eeskujuks ümbruskonna väiketaludele, andes nendele tõuget seda eeskuju järgida. Tulevikus, kui selle järele ehk vajadust peaks olema, võiks Petserimaale avada ka üks põllutöökool.

\section{Maapidamise ümberkorraldamine vastavalt väikemaa pidamise nõuetele}

Põllumajanduse produktiivsuse tõstmiseks tuleks ümber korraldada vastavalt väikemaapidamise nõuetele Petserimaa talude maapidamine, mis oleks rohkem tulutoov. Mil moel see ümberkorraldamine sünniks ja missugune majapidamise viis väikemajapidamises tulutoovam oleks, see jäägu vastavate asjatundjate otsustada. Ka tuleks kõigi abinõudega põllumaaks kõlbulikku maa-ala suurendada Petserimaal kui ka sisemaal asuvate soode kuivatamise teel. Sel alal oleks tööd palju ja meie töötatöölised, eriti petserlased, leiaksid kestvamat tööd.

\section{Soode kuivatamine}

Petserimaal leidub sellekohaseid soid, mida võiks kuivatamise teel kõlbulikuks põllumaaks muuta, küllaldaselt. Mõne soo pind on kaunis kõrge ja kuivatamine tasuks end lühikese aja jooksul ära. Pihkva piirkonna sood Senno, Satserinna, Kulje, Järvesuu ja Mäe valdades leiaksid kuivatamist ainult järvepinna alandamisega. Missuguste soode kuivatamiseks järve veepinna alandamine kaasa mõjub ja millisel määral, see jäägu asjatundjate otsustada. Sama võiks ütelda ka Irboska ja Senno valla soode kohta. Senno vallas on suuremateks soodeks Luki, Podgramje, Saputje ja Iveritsa sood, nendest on Luki sood, tema kõrge pinna tõttu kerge kuivatada. Selle õhtakallak lõpeb Halahalnja mõisa juure orgu, kus vee langemine kolmneli sülda. Selle soo kuivatamine avaldab oma mõju kindlasti ka Saputje ja Podgramje küla juures olevatele soodele. Kui palju nende kõigi soode kuivatamine läbiviidav on ja missugused kulud sellega seotud, selle otsustamine nõuab eri kaalutlusi. 


\section{Võsastikkude ülesharimine}

Ka leidub Senno ja Irboska valla piirides - Grädiste, Podgramje, Iveritsa, Lediste, Sababje, Sagrivje, Volkovo, Vana-Irboska ja Kilski ümbruses põlluharimiseks kõlbulikku maad, mis kaetud võsastikuga ja mis kerge üles harida.

\section{Halahalnja mõis}

Petserimaal on üheks nurina põhjuseks ka Senno vallas asuv Halahalnja mõis, mis välja renditud, kuid rentniku poolt ei harita maad korralikult, osa on sööti jäetud, väetamine puudulik, mille tagajärjel pinna poolest hea paemaa annab väheldast saaki. Nimetatud mõisa omanikuga, kes Belgia kodanik, tuleks kuidagi maa omandamise asjus kokku leppida, riigi valdamisele üle võtta ja elujõulisteks asundustaludeks välja anda sisemaa eestlastele.

\section{Liivamaad ja nende kasutamine}

Petserimaa põhjapoolses osas, Vilo, Satserinna, Senno, Järvesuu ja Kulje valdades asuvad suured liiva maa-alad, millel kohati tuiskav liiv leidub ja vilets võsastik kasvab. Ka nende kasutamist tuleks võimalust mööda kaalumise alla võtta ja kus maapind seda lubab - mets peale külida. Püüe neid liivalagendikkusid põllumaaks muuta, oleks täiesti asjata rahakulu ja ei annaks mingisuguseid reaalseid tagajärgi. Metsa, eriti männa, pealekülv oleks kaugelt otstarbekohasem ja kergem teostada, tooks riigile tulevikus tulu, annaks ehitus- ja küttematerjali. Metsatöödel saaks paljud kohalikud elanikud, eriti naised, tööd.

\section{Ühistegevus ja selle ergutamine. Ühistegelised ettevõtted ja asutused}

Majandusliku olukorra parandamiseks tuleks Petserimaal elustada ka ühistegevust ja et selleks Petserimaalt algatajaid vaevalt loota, siis avada sisemaa ühistegeliste ettevõtete osakonnad. Need uued asutused ei tohiks aga muutuda liiakasuvõtjateks, mis praegu moes. Nii sammus liiakasuvõtjatega ühes ka Petseri majandusühisus, kelle Irboska osakond, peaühisuse teadmisel, müüs kaupu võlgu vekslite vastu sama protsendiga ja sama tähtajaga, nagu erakaupmehed-liiakasuvõtjadki. Tuleks ergutada majandusühisuste ja tarvitajaühisuste asutamist, kust külamehed, kes ühisuse 
liikmed, võimalikult madalama ja õiglase hinnaga põllu- ja majapidamiseks tarvilikke tarbeaineid saaksid enestele muretseda. Samuti oleks nende ühisuste ülesandeks ka külameestelt põllumajanduse saaduste ülesostmine ja võimalikult väikese vaheltkasu eest turule toimetamine. Karjakasvatamise õhutamiseks rajada suuremate külade piirkonda katsena mõni üksik piimaühisus ja selle asjaajamine nii sisse seada, et ta ühtlasi ka virgutaks inimesi karjakasvatamisele enam tähelepanu pöörama, nähes selles tuluallikat. Katsena võiks niisuguseid ühisusi avada Irboska-Senno piirkonda ja teistesse valdadesse, peale Rootova, Laura ja Meremäe, kus juba piimaühisused olemas. Karjapidamise edenemisel võiks suuremate meiereide peale üle minna. Tuleks ergutust ja hoogu anda ka igasuguste masinatarvitajate ja laenu-hoiu ühistute asutamiseks.

\section{Käsitöö ja selle edendamine. Ehitustöölised}

Majandusliku olukorra parandamiseks aitab palju kaasa ka igasugune

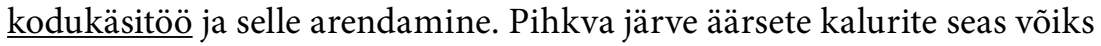
heaks käsitöö alaks olla kalavõrkude kudumine, mida kõik naised ja mehed oskavad. Võrkude kudumiseks oleks kohane nendele vastav materjal, odavama hinnaga, soodsatel tingimustel kätte toimetada või jälle tasu eest lasta kalameeste või teiste ühistegeliste asutuste poolt võrkusid kududa, kes siis need võrgud tarvitajatele võimalikult väiksema tasu eest edasi müüks ja kaluritele toetusena välja jagaks. Rahalise toetuse andmine kaluritele ei ole soovitatav, see kulutatakse muuks otstarbeks ja püügiriistad jääksid ikkagi muretsemata. Üldse on Petserimaal käsitöö vähe arenenud ja põhjalikult ei tunne Petserimaa kodanik, välja arvatud kalavõrkude kudumine, õieti ühtegi käsitöö ala. Tarvilikumad käsitöölised, nagu sepad, rätsepad, kingsepad, tislerid jne. on omal alal viletsad töömehed ja võivad rahuldada ainult Petserimaa vähearenenud nõudeid. Käsitöö edendamiseks ja oskuse tõstmiseks tuleks korraldada, kas vastavaid kursusi või asutada mõni käsitöökool, kus oleksid esitatud hädatarvilised käsitöö alad, ka söögikeetmine kaasa arvatud. See kool peaks olema soovijatele kättesaadav, arvestades nende majandusliku seisukorraga. Tuleks hoiduda moodsa käsitöökooli avamisest, mis liig kulukas ja vähemalt praegustes oludes Petserimaale mittekohane. Ehitustöölistest leidub Petserimaal suurel arvul häid kivitee ehitajaid, puutöölisi, kivi- ja müüritöölisi, kes võiksid rahuloldavalt ka sisemaa ehitustöö nõudeid täita. Tööpuuduse vähendamiseks oleks soovitav nende sisemaale juhtimine. Kodanikkude majandusliku olukorra parandamise peale tuleks tõsist tähelepanu pöörata ja majanduse tervendamiseks kõik võimalikud abinõud ära kasutada. Kui kaob majanduslik 
kitsikus, kodanik saab rahuloldavalt ära elada, siis kaob ka nende poliitiline meelsus ja vaenulikkus Eesti riigi vastu. Praegune vaenulikkus ja sümpaatia N. Venemaale on tingitud peaasjalikult majanduslikust viletsusest ning kodanikkude äärmisest kehvusest.

\section{Üldine tööpuudus}

Petserimaa majapidamised, kus keskmiselt 6-10 liikmelise perekonna kohta 3-4 tiinu maad, ei suuda ka kõige radikaalsema kasutamise viisi juures kodanikke ära elatada ja nad on sunnitud kõrvalteenistust otsima. Et koha peal puuduvad püsivad tööleidmise võimalused, siis jääb loomulikuks tööotsimise kohaks Sise-Eesti. Tsaari ajal leidsid Petserimaa kodanikud teenistust Venemaal, peaasjalikult Petrogradis, kus pea iga teine praegune keskealine venelane on käinud, samuti ka kalurid püügi vaheaegadel. Eesti Vabariigi rajamisega on Venemaal tööleidmise võimalused ära lõigatud, mis ka teatud riigivaenulikkuse põhjuseks on.

\section{Töövõimalused sisemaal ja selle takistavad põhjused}

Ka Sise-Eestis on Petserimaa kodanikkudel raske teenistust leida keeleoskamatuse, teenistuse kohtade teadmatuse ja muil põhjustel. Paljudel juhtumistel tuleb tööotsijail sisemaal nädalapäevade otsimise järele teenistust leidmata kodukohta tagasi pöörata. Mõned venelased peavad sisemaal tööotsimist koguni alandavaks ja nurisevad, et nendega seal halvasti ümber käiakse; üldse ei taha nad "tsuhnate" juures teenida. Nurisetakse sisemaa toiduolude üle, olgugi, et kodus midagi paremat ei söö ja poolnäljas elavad. Nurinaid kuuldub ka madala töötasu ja selle kohta, et eestlased nende kombeid ja usulisi traditsioone pilkavad, mille tagajärjel paljudes venelastes vihavaen ja põlgus eestlaste vastu.

\section{Pahempoolse elemendi kihutustöö sisemaale töölemineku vastu}

Sisemaale töölemineku vastu on ka Irboska-Senno pahempoolsed; nii esines avalikul koosolekul möödunud aasta sügisel Nikita Semenov ${ }^{18}$ töötatööliste küsimuse asjus, andes nõu sisemaale mitte tööle minna, sellega surutavat töötasu alla. Töölemineku asemel soovitas pöörata töötatöölistel valitsuse poole palvetega toetuse saamiseks. Praegusel ajal sõidavad Irboska-Senno venelased sisemaale tööle, peaasjalikult turbarabadesse.

18 Juhtiv liige sotsialistide grupi vene harus 1920. aastatel. 


\section{Sisemaale töölemineku juhtimise organiseerimine. Tööbörsid ja nende tegevuse kavad tööle juhtimisel}

Sisemaale tööleminekut raskendab ka asjaolu, et puuduvad koha peal teated, kus on võimalus tööd leida, missugust, mis tingimusel, kui kauaks ja missuguse tasu eest. Siin tegutsevad tööotsijad organiseerimatult, omal algatusel, ühest kohast teise ümber sõites. Töö mitteleidmisel kantakse, loomulikult, vihavaenu Eesti ja eestlaste vastu ning siunatakse neid igat pidi. Töö leidmise hõlbustamiseks oleks soovitav, et sisemaa tööandjad pööraksid tööliste nõudmisega Petseri maavalitsuse või selle juure asutatud tööbörside poole, ära näidates missuguseid eriala töölisi, mehi või naisi, kui pika aja peale, missugustel tingimustel, millise tasu jne. eest nad vajavad. Niinimetatud asutuse poolt tuleks need nõuded vallavalitsusele edasi saata, nad siis töösoovijatel saadaval oleksid. Et mitte ühte kohta üle kuhjamist ei oleks, siis peaks tööle saatmist juhtima üks asutus. Tööle sõitmise hõlbustamiseks tuleks pikemaks ajaks, näit. üle kahe kuu, töölesõitjatele kergendusi teha sõidutariifi alandamise või sõidukulude avansina etteandmise näol, mille tõenduseks võiks dokument tööandjale ettevõttele saata, kes siis sõidukulud töötasust kinni peab ja avansseerijale asutusele tagasi maksab. Priisõidu andmine ei ole soovitav, see ahvatleks asjata sõitmisele. Peale sisemaal tööleidmise tuleks ka koha peal kõik võimalused tööpuuduse kõrvaldamiseks ära kasutada.

\section{Töövõimalused kohalistes tööstusettevõtetes ja nende seisukord}

Praegu on Petserimaal üheks suuremaks alaliseks tööstuseks Irboska kipsivabrik. Kipsitööstus, mis omal ajal õitseval järjel asus, andis sadadele ümbruskonna kodanikkudele tööd ja teenistust, kuid praegu kiratseb see tööstus ja seal võivad ainult vähesed tööd leida. Vabrikul puudub raha, milles süüdi korratu asjaajamine. Vabriku tegelaste ringkonnas kuuldub ütelusi, et vabrikul olla tellimisi palju, kapitali puudusel ei suudetavat neid täita. Olgugi, et tööstusel tellimisi, tööjõud odav ja veovõimalused head (otse jaama juures), siis tuleb lugeda vabriku kiratsemise põhjuseks administratsiooni lohakust ja saamatust ning suuri kulusid selle üleval pidamiseks... Tööstuse edendamiseks olla vabrik isegi valitsuselt või Eesti pangalt laenuna toetust saanud, mis ka administratsiooni peale ära kulutatud. Vabriku poolt sünnib töölistele tasumaksmine alati viivitusega; varem sündis see vabrikupoest koguni kaupade näol. Teiseks suuremaks tööstuseks Petserimaal on Põlgino (Šumilovo) põllutööriistade vabrik Rootova vallas. See valmistab peaasjalikult tuulamise masinaid. Ka see tööstus on läbi 
põlenud. Vabriku omanik Andersoni poolt on tööstuse peale Eesti pangast miljonilised võlad tehtud; peale selle veel võlad teistelt asutustelt ja isikutelt, missugune raha pole mitte tööstusesse rakendatud, vaid Andersoni poolt kuritahtiliselt ära tarvitatud. Nüüd on vabrik õieti oma tegevuse lõpetanud ja varandus võlgade katteks aresti all. Seegi vabrik suudaks mõnele kümnele töölisele teenistust anda. Nende kahe tööstuse elustamisega saaks nii mõnigi töötatööline rohkem tööd. Hea korralduse ja tahtmise juures, võiks mõlema vabriku saadustele välisturgugi leida.

\section{Tööpuuduse vastu võitlemine}

Petserimaal tööpuuduse vastu võitlemiseks tuleks kõik koha pealsed kui ka sisemaalased võimalused ära kasutada ja töötatöölisi juhtida produktiivsetele rahvamajanduslikele aladele, eeskätt põllumajanduse tõstmisele ja muule loovale tööalale, mis suudaks väärtusi luua ja meie kehva rahvamajandust rikastada. Nii võiks töötatööliste abil laiaulatuslikke soode kuivatamisi, Pihkva-Peipsi järve veepinna alandamist, esimese järgu tähtsusega teede parandamist jne. ette võtta.

\section{Turbarabade kasutamine}

Ka tuleb asuda intensiivsemale turbarabade kasutamisele; ergutada turbatööstuse paremale järjele tõstmist Luki, Podgramje, Senno, Miltsõi ja teistes turbarabades; õhutada turba tarvitamist kütteainena ja aluspõhuna. Heaks tuluallikaks võiks kütteturvas saada Senno ja Irboska vallas ning suureks toeks olla nende valdade metsavaestele küladele. Laialdane turba tarvitamine annab paljudele tööd ja hoiaks tagasi metsade laastamist. Turbatööstuse edendamiseks ellu kutsuda turbaühisusi.

\section{Piiripoliitika ja selle siht}

Käsikäes majandusliku olukorra parandamisega peaks muutuma ka meie piiripoliitika. Sõna tõsises mõttes meil on senini puudunud kavakindel ja sirgejooneline piiripoliitika, kõik on lastud nagu omapead minna, on puudunud kindel kava, mis korraldaks Petserimaa elu ja poliitilist ilmet Eesti riikluse kohaselt, mille sihid ulataksid kaugemale tulevikku, looks põhjapaneva aluse Petserimaa arenemisele Eesti riiklikus suunas, moodustaks Petserimaa ümber Eesti riigi orgaaniliseks osaks, millele oleks võõras püüd ja poolehoid Idale. 


\section{Elujõulised piiriäärsed majapidamised}

Selleks on tarvis põhjalikult muuta Petserimaa majanduslikku ilmet: praeguste kiratsevate väikemaapidamiste asemele piiriäärses rajoonis asutada elujõulised ja eeskujulikud talud, maad nende asutamiseks mingi asutuse või panga kaudu, riigi raha toetusel, kiratsevatelt külavenelastelt kokku osta. Venelastele soodsamatel tingimustel sisemaal maad asemele anda ja hõlbustada toetuse ning prii veokulu abil nende sinna üle kolimist. Aga nendele, kes soovivad maalt välja rännata - seda ka võimaldada või isegi selleks kaasa aidata, sest sarnastest nii kui nii korralikke Eesti kodanikke ei saa.

Uutesse, elujõulistesse taludesse paigutada ainult sisemaa riigitruid eestlasi, nendele soodustusi anda majapidamiste eeskujulikuks kordaseadmiseks. Sellega seotud kulud tasuvad endid pikapeale ausasti ära ja kaoks igasugune urgitsemine poliitilisel alal piiril N. Venemaa poolt, sest siis puudub sellele vastuvõtlik element. Samuti tuleks ka setu valdades muuta majapidamisi elujõulisemaks rahvaarvu vähendamise ja majapidamise produktiivsuse tõstmise teel.

\section{Hariduspoliitika ja õpetajaskond}

Teiseks piiripoliitika osaks olgu ka sirgejooneline hariduspoliitika. Praegune õpetajaskond jätab soovida; see pole omas enamuses täitsa eestisõbralik. Kuigi enamus poliitikas ei ole aktiivselt tegev, vaatavad nad Eesti riigi ja selle huvide peale passiivselt; sama passiivsust istutatakse ka noorsoosse edasi. Õpetajatest on paljud endised vene rahvusest emigrandid ja P.-L. armee ohvitserid, kes kuidagimoodi Eesti kodakondsusesse vastu võetud; ainult mõned üksikud on veel kodakondsuseta. Enamus nendest vaatab Eesti riigi, nagu ajutise riigi või oma peatuskoha peale, loodavad kunagi tulevikus Eesti ühinemist Suur-Venemaaga ja peavad endid ajutisteks Eesti kodanikkudeks. N. Venemaal olude muutumisel pööravad nad esimesel võimalusel oma kodukohta tagasi, kus tegevuse väli laialdasem, väljavaated ning karjärivõimalused suuremad. (Sarnaseid mõtteid mõlgutavad isegi mõned eestlased-optandid). Õpetajaskonna poolt antakse need vaated edasi ka noorsoole. Paljud oppetajatest on umbkeelsed venelased, mõned on häda sunnil õppinud puuduliku eesti keele, mille vastu neil puudub huvi ja lugupidamine. Sarnasel puudulikul viisil oppetatakse riigikeelt ka noorsoole. Isegi Petseri keskkooli lõpetajad valdavad puudulikult eesti keelt. 
Endise koolinõunik Usai ${ }^{19}$ poolt viidi parteipoliitika (ESTP) ka õpetajaskonda ja paljud ópetajad, püüdes temale meelepärast olla andusid parteipoliitika tegevusele, kaldudes õppetööst kõrvale, mis halvavalt koolitöö peale mõjus. Usai asemele valitud uuest koolinõunik Truusmann' is ${ }^{20} \mathrm{ei}$ ole ka midagi paremat loota. Tema on tuntud Vene rahvusluse pooldajana, kelle huvid Eestile võõrad või koguni enamgi, missuguses sihis on loota ka tulevikus tema mõju.

\section{Opetajate valimine ja selle pahed Petserimaal}

Üheks paheks Petserimaal on ka õpetajate valimine vallavolikogude poolt. Praeguse vallavolikogude hariduslikult madala tasapinnalise, omakasupüüdjate, viinaarmastajate ja mitte täitsa eestimeelse isikulise koosseisu juures, saavad harilikult õpetajateks valitud niisugused isikud, kes suudavad valla volinikke rohkem viinaga kostitada või kellel kuidagi isikulised suhted volikogu mõjuvamate isikutega (liikmetega). Kostitamise ja muu meelehea andmisega saavad hakkama enamasti kindluseta ja kõikuva ilmavaatega isikud ja siis ei saa sel teel loomulikult Petserimaa koolipõllule tublid ja Eesti rahvusriikluse aatega õpetajad valitud.

Praeguse õpetajaskonna enamuse kohta võib kindlasti ütelda, et nad ei seisa oma ameti kõrgusel, rääkimata riiklikust tublidusest. Paljud õpetajad on halbade elukommetega ja ei suuda pakkuda kasvandikkudele ning ümbruskonnale mingit head eeskuju. Et Petserimaa koolipõllule saaks riiklikult ustavaid ja eeskujulikke õpetajaid, tuleks kas või seaduse andlikul teel praegune valimise kord muuta ja õpetajad jäägu haridusministeeriumi määrata, kellel siis avaneb võimalus Petserimaale eeskujulikke õpetajaid määrata, kes tõesti tahavad ja suudavad seal maksma panna ja läbi viia Eesti riikluse aadet vastavalt kavakindlale piiripoliitikale ka hariduspõllul ning Eesti riikluse heaks laiemas rahvakihis kihutustööd teha. Õpetajad ei tohiks anduda parteipoliitikale, nende poliitika olgu üldine Eesti rahvusriiklik. Õpetajate olukorda Petserimaal tuleb nii palju parandada, et ka kõrgema haridusega jõud ei põlgaks sinna teenistusse tulla.

\footnotetext{
19 August Usai (snd 04.12.1880) - Petserimaa koolinõunik aastatel 1920-27. Eesti Sotsiaaldemokraatliku Töölispartei Petserimaa komitee esimees, kes osutus 1932. aastal Riigikokku valituks. 1940-41 töötas Petseri Gümnaasiumi direktorina.

20 Arvatavasti on siinkohal mõeldud Paul Truusmanni (snd 19.01.1888) - õppis Peterburi Ülikoolis ajaloo-filoloogia osakonnas, mille lõpetas 1910. Alates 1911. aastast õpetas Tallinna Aleksandri Gümnaasiumis, kus töötas aastani 1920. Aastatel 1920-23 määrati ta Petseri Reaalgümnaasiumi juhatajaks. Alates 1923. aastast töötas Võru Õpetajate Seminaris õpetaja ja raamatukoguhoidjana. RA, ERA.1108.10.1922.
} 
Peaaegu keegi õpetajatest seltskonna tegevusest osa ei võta; ei suuda või ei taha noorsoole mingit meelsat ajaviidet korraldada aidata. Seltskonnategevuse alal on Petserimaa õpetajail väga palju teha, milleks hea tahtmise juures võimalused ei puudu: küla võõrutamine küla simmanitest-guljanjedest, vana kalendriviisi tarvitamisest; õhutada ühistegevust, korraldada ja organiseerida mitmesuguseid üldhariduslikke seltse, süvendada ja arendada isamaatunnet jne., mis kõik õpetajal, kui lihtrahvale lähedal ja alalises läbikäimises seisval isikul kergem teha oleks, kui mõnel teisel, selleks määratud, erilisel instruktoril, kelle tegevus ei suuda kunagi anda neid tagajärgi ja peale selle, olles seotud suurte rahaliste kuludega.

\section{Kirikud riikliku propaganda abinõuna ja kalendri ühtlustamine}

Petserimaal, kus usuline tunne sügavale rahva hinge juurdunud, tuleks ka usku riikliku propaganda mõttes ära kasutada, vähemalt setude seas. Et setusid Luteri koguduste ümber raske koondada, siis tuleks Petserimaale määrata sirgejoonelist Eesti riiklikku poliitikat teostavad ap.-õigeusu vaimulikud Eesti rahvusest ja seda kindlasti setu kogudustesse, kes rahvale arusaadavas keeles jumalateenistusi peaksid ja vaimulikul alal Eesti rahvusriiklikku tunnet arendaksid ning aitaksid Petserimaad Sise-Eestile lähemale viia. Ei tohiks jätta kasutamata püüdu setusid ka Lutheri koguduste ümber koondada, sest Lutheri kirik on aja jooksul Eesti rahvusest vaimulikkude juhtimisel enam-vähem Eesti riiklikus orientatsioonis arenenud ja suudab sellel alal rohkem ära teha, kui ap.-õigeusu kirik.

Ka kalendri küsimus tuleks sisemaaga kiriklikes toimetustes kindlasti ühtlustada. Praegune kalendri vahe tuletab rahvale alati meelde vahekorda Sise-Eesti ja Ida vahel. Kalendri ühtlustamisel tuleb ap.-õigeusu kõrgemal juhil kindla käega, igasuguseid kõrvalekaldumisi tegemata, - talitada. Mitmesugune kalendriaeg toob sekeldusi majanduslikus läbikäimises, ametitalitustes ja koolides.

\section{Riikliku propaganda puudus ja vaenuliku elemendi tegevus}

Piiripoliitika kavas peaks kindlasti olema ka riiklik propaganda. Senini on see väga nõrgal alusel, on peetud ainult mõned kihutuskõned poliitiliste erakondade poolt, mis laiematesse hulkadesse mingit jälge pole jätnud. Selle vastandina tegutseb Eesti riikluse vastasrind vahet pidamata Petserimaal, keda piiri tagant toetavad N. Vene agitaatorid. 


\section{Nikita Semenovi ja tema pahempoolsete talupoegade rühmituse} tegevus

Riigivaenuliku meelsuse õhutajatest väärib kõige rohkem tähelepanu Riigikogu liige Nikita Semenov ja tema käsilased. Viimased on Petserimaal praegust ainsam organiseeritud ja aktiivselt tegutsev poliitiline rühmitus, kes omad agendid laiadesse rahvahulkadesse poetanud ja palju poolehoidu suutnud võita igasuguste lootustäratavate ja lubadustega täidetud kihutustööga. Semenov, kes endine enamlaste aegne tegelane ja kelle kaks venda praegugi N. Venemaal kommunistid, on oma ümber koondanud piiriärrse aktiivsema pahempoolse elemendi, kelledest paljud enamlaste aegsed tegelased ja tuntud eestivaenulisena. Oma rühmituse organiseerimise ja III-da Riigikogu valimiseelsel kihutustöö hooajal tegi Semenov oma kaaslastega kõige energilisemat kihutustööd ja andis lubadusi Riigikogusse pääsemisel võimaldada vaba läbikäimist N. Venemaaga, nõutada piiriäärsetele viletsusest kannatavatele kodanikkudele abi või toetuse saamist N. Venemaalt. Rahvas, kes elab viletsuses, oli liig vastuvõtlik nendele lubadustele, uskus Semenov'i võimetesse ja loodab seda veel praegugi. Viimasel ajal on Semenov, tema vastu tõstetud süüdistuste tagajärjel, oma kaaslastega avalikust meelsust õhutavast kihutustööst tagasi tõmmanud ja piirdub peaasjalikult kodanikkude majanduslikult viletsa olukorra, maksude korralduste, valitseva tööpuuduse ja muude hädade valgustamisega omast vaatepunktist. Selle juures antakse mõista, et siin on ikka süüdi Eesti praegune riiklik kord ja paranemist on loota ainult siis, kui nemad, s.o. Semenovi rühmitus, omavalitsuse asutustesse pääsevad. Niisuguste eitavate külgede valgustamine, kus veel eeskujuna seatakse N. Venemaad, süvendab kodanikkudes ainult Eestivaenulist meeleolu ja sümpaatiat N. Venemaale. Peale selle aitavad riigivastast meelsust levitada ja süvendada veel igasugused salaja ülepiiri käijad isikud ja N. Venemaalt, Eestisse saadetavad kirjad ning Vene kalurite suusõnalised seletused meie kaluritele, kokkupuutumisel järvel kalu püüdes.

\section{N. Vene piiripoliitika ja piiritagused miitingud kihutustöö abinõuna}

Meie piiriäärsete kodanikkude seas N. Vene heaks meelsuse loomiseks on

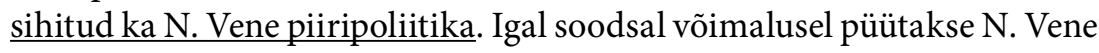
võimude poolt Eesti, kui ka teiste rajariikide olukorda ja poliitikat maha teha, oma ülistades. Selleks tehakse N. Vene piiriäärsetele kodanikkudele teatud soodustusi, antakse omanikkudeta maad neile tasuta kasutada ja 
püütakse muidu majanduslikku olukorda piiri ääres parandada, mis ka meie piiriäärsetel kodanikkudel hästi teada. Kihutustöö mõttes korraldavad N. Vene võimud mitmesugustel tähtpäevadel piiril miitinguid. Neil päevadel kogutakse piiri erapooletu maariba joonele suured rahvahulgad, räägitakse nendele $\mathrm{N}$. Vene tõusvast majandusest, tööliste ja talupoegade vabadusest, suurtest tuleviku plaanidest ja seatakse vastandina raja- ja teisi Euroopa riike, kus töölised kannatada kapitalistide surve all, neid kiusavat taga poliitiliste vaadete pärast ja neil puududa isegi vabadus liikumiseks, mille näituseks olla asjaolu, et meie, s.o. Eesti, poolt ei lubata piirile ühtegi kodanikku, kuna $\mathrm{N}$. Vene võimud on piirile lasknud omi kodanikke, kes võiksid kokku saada, piiril, Eestis elavate omastega, nendega mõne sõna jutu ajamiseks.

Vastuabinõuna sellele N. Vene kihutustööle oleks kõige otstarbekohasem, meie poolt, piiriäärses maaribas elutsevate kodanikkude majandusliku olukorra tegelik parandamine, mis tegelikult näitaks, et elu Eestis parem on kui N. Venemaal ja sellega oleks siis ka Vene agentide kihutustöö enam-vähem halvatud.

\section{Salaja üle piiri käimise vastu võitlemine}

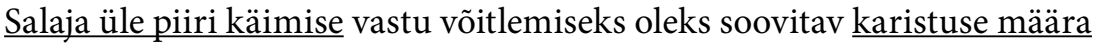
rahatrahvi kõrgendamine, kuna vanglakaristus endiseks võiks jääda. Praegune rahatrahvi ülemmäär, kuni 3000 margani, on liig madal ja võimaldab kergesti selle tasumist. Ka tuleb sel moel N. Venemaal käimine odavam, kui ametlikult. Karistuse abinõuna üle piiri käimise eest tuleks salaja ülekäijaid piiriäärsest rajoonist välja saata, mis korduvatel juhtumistel tingimata peaks sündima. Rahatrahvi ülemmäär võiks olla mitte alla 30000 marga.

\section{Emigrandid}

Petserimaa üheks paheks on ka Vene emigrandid, keda seal elab 820 isiku ümber. Suuremal osal nendest puudub kindel teenistus ja elatavad endid juhuslikust tööst. Kindla teenistuse puudusel siunavad nad Eesti vabariiki ja selles maksvat korda. Eestivaenulikkust ei avalda mitte ainult tööta emigrandid, seda teevad isegi majanduslikult kindlustatud. Nende ja teiste kodakondsuseta isikute piiriribas ja selle läheduses ei ole kuidagi soovitav ja nende eemaldamine võiks ainult kergendust tuua kohalikkude elanikkude seisukorra parandamiseks. Ainult mõnele üksikule emigrandile, kes on poliitiliselt Eesti suhtes lojaalne, võiks erandi teha. 


\section{Tulikahjud ja nende vastu võitlemine}

Majapidamisele ja julgeolekule on hädaohtlikud ka sagedased tulikahjud Petserimaal. Nende põhjusteks on suuremalt jaolt lagunenud korstnad, truubid ahjud, õlgkatused, plekk-korstnad, mis vaevalt välja ulatuvad õlgkatusest, jne. Praeguse külade süsteemi juures võivad need, suuremate tulekahju juhustel, tervetena maha põleda. Tuletõrje eriti Petserimaal on väga puudulik ja nõrk ning viletsate abinõudega ja veepuudusel, ei suuda isegi vaikse ilmaga tulele piiri panna. Tulekahjude vastu võitlemiseks tuleks Petserimaal vastavad sundmäärused maksma panna, nende täitmise järele valvavad külavanemad, kuna üldkontroll sel alal, jääks politsei hoolde. Oleks soovitav, et tuleõnnetuste vastu hoonete ja varanduste kinnitamisel hindamine sünniks valla omavalitsuse asutuse tegelaste poolt, et ära hoida kinnitamisel varanduse kinnitaja, kui ka selle omaniku kasusaamise eesmärke.

\section{Kaklused ja pussitamised külades}

Kaklused ja pussitamised vene ja setu külades on saanud igapäevaseks nähtuseks, eriti külapidustustel-guljänjetel. Tihti lõpevad sarnased pidud tapmisega. Nende pahede kõrvaldamiseks oleks soovitatav, et karistuse normid saaksid kõrgendatud ja määratud administratiivkorras, nagu see oli varem. Siseministri poolt karistamise ajajärgul oli kaklusi kaugelt vähem kui praegu.

\section{Omavalitsuse asutuste tegevus ja asjaajamine}

Petserimaa omavalitsuse asutustelt tuleks rohkem sirgejoonelisemat riiklikku poliitikat nõuda ja selle läbiviimiseks nendes põhjalik puhastustöö ette võtta. Nad on praegu tihti nurinate põhjuseks kodanikkude seas. Kaevatakse väga tihti joomingute kohta omavalitsuse asutustes, vastutulematuse ja asjaajamise üle, kus asju õiendatakse tihti viina mõjul. Eriti sünnib see vallavolikogudes tähtsamate küsimuste otsustamisel, nagu õpetajate või valla ametnikkude valimisel. Maavalitsuse järelevalve on nõrk; vähemalt seda senini olnud ja praeguse maavalitsuse kohta ei või, tema nooruse tõttu, veel midagi ütelda, tema teguvõimet näitab tulevik. Kodanikud näevad omavalitsuse asutuste tegelastes ainult omakasu püüdjaid, kes kipuvad selleks omavalitsusse, et saades võimule, kõrvaldada rahva raha või mõne muu ärikombinatsiooniga ennast rikastada. Kõige rohkem oli see moes Beresini võimuloleku ajal, siis oli nagu hüüdsõnaks: "mida halvem, seda 
parem". Maavalitsuse eeskujul toimetas siis ka enamus valla ametnikest, mille näituseks raha kõrvaldamised Satserinna, Senno, Rootova, Irboska ja Järvesuu vallavalitsustes. Lohakuse poolest on Petserimaa valdade asjaajamine kuulus eriti Petseri vallavalitsuses. Viimases puudub isegi korralik valla elanikkude nimekiri.

\section{Vallasekretäride valimine ja selle pahed Petserimaal}

Loetletud pahede kõrvaldamiseks tuleks seada vallasekretärideks asjatundlikud, täiesti ausad, kained ja poliitiliselt väljaspool erakondi seisvad isikud, kes oleksid juhitud asjaajamisel Eesti riiklikust poliitikast. $\underline{\text { Senise }}$ valimise korra asemel tuleks sekretärid kohtadele määrata, siis vabaneks nad vallavolikogu mõju alt, mis praeguste Petserimaa vallavolikogude isikulise koosseisu juures, kes arenemata ja omakasupüüdjad, väga halvavalt mõjub sekretäri iseseisvuse peale. Koha kinnihoidmise mõttes tuleb sekretäril vallavolikogu liigete poolehoiuga liig palju arvestada. Petserimaal on sekretäre, kes alguses täiesti Eesti riiklike vaadetega olid, kuid pikapeale vallavolikogu liigete mõjualusteks muutunud. Ka tuleks sagedamini omavalitsuse asutusi revideerida, kus revideerimisele ei pea kuuluma mitte ainult raha asjad, vaid terve asjaajamine, täies ulatuses. Igasuguste väärnähtuste kõrvaldamist nõuda kindlateks tähtaegadeks.

\section{Liigjoomine ja selle vastu võitlemine}

Petserimaal joodaks aasta jooksul hiigla summad maha. Kõige rohkem on joomine arenenud venelaste seas, kuna setude seas alkohoolikute protsent väiksem, - nad joovad enamasti eetrit. Kõige rohkem juuakse külapidustustel. Viina muretsemiseks tehakse tihti vekslite vastu laenusid, liiakasu võtmise hooajal anti isegi riigi viinapoodidest vekslite vastu viina võlgu. Joomist hõlbustab rohke viinamüügi kohtade arv ja salakõrtsid. Praegu võib Petserimaal igast külast ja külakauplusest viina saada. Salakõrtside vastu võitlemine on politseil väga raske, kättemaksu kartusel ei taha keegi tunnistajana esineda. Joomise vastu võitlemiseks tuleks joogikohtade arvu võimalikult vähendada, nendest alkoholi väljaviimine kõvasti keelata või nad üldse sulgeda. Salakõrtsmikkudele kõige valjemad karistused määrata, korduvatel juhtumistel aga maalt välja saata. 


\section{Ametnikud ja nende teenitustingimused Petserimaal}

Üldiselt kuuldub ka ametnikkude seas kaebusi teenistustingimuste kohta Petserimaal, peetakse neid, võrreldes sisemaaga, ebanormaalseks, elamistingimusi raskemaks ja ülespidamist ning kortereid kallimaks. Niisuguste tingimuste tagajärjel katsuvad ustavamad, eeskujulikumad ja rohkem arenenud ametnikud esimesel võimalusel Petserimaalt lahkuda ja sisemaale vastavat teenistust leida, kus teenistus kergem, elu odavam ja korteriolud lahedamad, kuna teenistuse tasu igal pool ühesugune. Paremate ametnikkude Petserimaale juhtimiseks ja nende seal kinnipidamiseks oleks soovitav ja tarvilik palgasoodustused lisatasu näol laiendada kõigi ametkondade peale, nagu see praegu maksev piirivalves, sõjaväes ja õpetajaskonnas. Palgakõrgendus oleks soovitav $30-40 \%$ võrra.

Võrus. 6. juulil 1927 a.

Lisa No 2. Andmeid Petserimaa elanikkude arvu, rahvusliku koosseisu ja pindala kohta.

\begin{tabular}{|c|c|c|c|c|c|c|c|c|c|}
\hline \multirow[b]{2}{*}{ Vald } & \multicolumn{4}{|c|}{ Elanike arv } & \multicolumn{5}{|c|}{ Maa suurus (tiinudes) } \\
\hline & 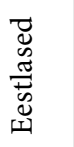 & 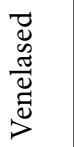 & 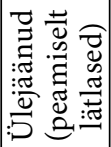 & $\frac{\vec{v}}{\underline{v}}$ & 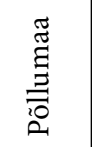 & 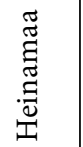 & 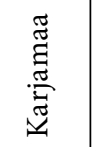 & 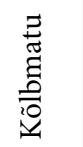 & $\sum^{\frac{\infty}{d}}$ \\
\hline Mäe & 2650 & 450 & & 3100 & 2826,4 & 1803,4 & 1752,8 & 614,3 & 1181,1 \\
\hline Kulje & 50 & 5510 & & 5560 & 749 & 1756 & 1001 & 960 & - \\
\hline $\begin{array}{l}\text { Järve- } \\
\text { suu }\end{array}$ & 2878 & 719 & & 3597 & 2937,6 & 1175 & 5315,8 & 4078,7 & 2463,5 \\
\hline $\begin{array}{l}\text { Satse- } \\
\text { rinna }\end{array}$ & 2300 & 1000 & & 3300 & 2830,2 & 749,9 & 2264,4 & 1628,9 & 2921,6 \\
\hline Senno & 550 & 7500 & 250 & 8300 & 6194 & 2007 & 1054 & 2146 & 738 \\
\hline Irboska & 247 & 9002 & 101 & 9350 & 6139,66 & 3769 & 2705,34 & 1107 & 558,78 \\
\hline Laura & 185 & 2651 & 591 & 3427 & & & & & \\
\hline $\begin{array}{l}\text { Roo- } \\
\text { tova }\end{array}$ & 190 & 2890 & 1712 & 4793 & 5741 & 2236 & 2614 & 1480 & 1474 \\
\hline Vilo & 4363 & 2566 & 43 & 6972 & 8832,1 & 2388,3 & 3054,3 & 1457 & 2348,5 \\
\hline
\end{tabular}




\begin{tabular}{|c|c|c|c|c|c|c|c|c|c|}
\hline \multirow[b]{2}{*}{ Vald } & \multicolumn{4}{|c|}{ Elanike arv } & \multicolumn{5}{|c|}{ Maa suurus (tiinudes) } \\
\hline & 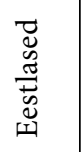 & 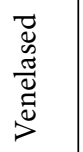 & 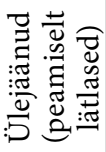 & $\frac{\vec{v}}{\frac{v}{0}}$ & 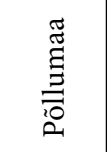 & 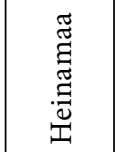 & 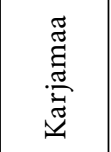 & 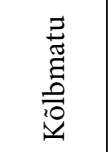 & $\sum^{\infty}$ \\
\hline $\begin{array}{l}\text { Mere- } \\
\text { mäe }\end{array}$ & 5158 & 479 & 51 & 5688 & 7659,6 & 1289,6 & 1968,3 & 1424,9 & 2362,5 \\
\hline Petseri & 1900 & 5000 & 100 & 7000 & 7140 & 1391,82 & 1581,60 & 1100,96 & 3448 \\
\hline $\begin{array}{l}\text { Petseri- } \\
\text { maa } \\
\text { kokku }\end{array}$ & 20471 & 37767 & 2849 & 61087 & 54516,86 & 19964,62 & 24945,74 & 17540,56 & 18349,79 \\
\hline
\end{tabular}

Märkus: Käesolevates andmetes on mõned ebatäpsused, sest Petserimaa omavalitsuse asutustes leiduva lohaka ja korratu asjaajamise tõttu, sealt täpseid andmeid saada on võimatu. Andmetes võivad olla mõne protsendilised kõrvalekaldumised.

Lisa No 3. Andmeid Petserimaa kooliõpetajate kohta

\begin{tabular}{|c|c|c|c|c|c|c|c|}
\hline & 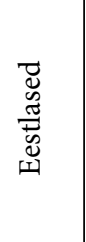 & 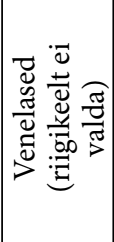 & 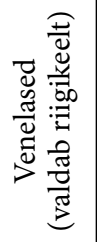 & 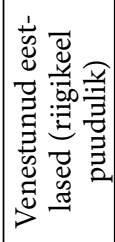 & 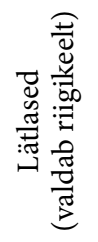 & 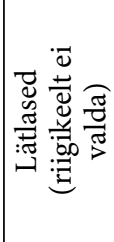 & 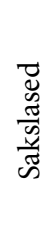 \\
\hline Mäe & 9 & 1 & & 1 & & & \\
\hline Kulje & & 14 & & 1 & & & \\
\hline Järvesuu & 10 & 3 & & & & & \\
\hline Satserinna & 6 & 2 & 1 & & & & \\
\hline Senno & & 13 & 9 & 1 & & & \\
\hline Irboska & & 15 & 15 & 1 & & & \\
\hline Rootova & 3 & 7 & 1 & & 2 & 2 & \\
\hline Laura & 1 & 7 & 2 & & 2 & 2 & \\
\hline Vilo & 20 & 4 & 1 & 1 & & & \\
\hline Meremäe & 16 & 3 & 2 & & & & \\
\hline
\end{tabular}




\begin{tabular}{|c|c|c|c|c|c|c|c|}
\hline & 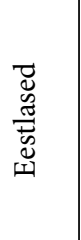 & 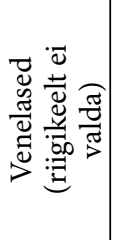 & 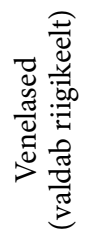 & 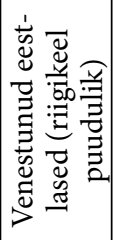 & 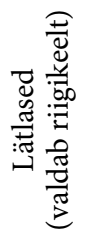 & 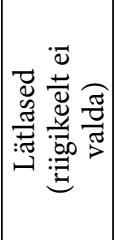 & 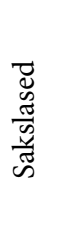 \\
\hline Petseri & 7 & 15 & 2 & & & 1 & \\
\hline $\begin{array}{l}\text { Petseri linn } \\
\text { (koos gümnaasiumiga) }\end{array}$ & 22 & 8 & 2 & & & 1 & 2 \\
\hline
\end{tabular}

Märkus: üksikasjalikud andmed iga kooliõpetaja kohta eraldi on "Petserimaa kooliõpetajate nimekirjas"

Nuder

Poliitilise Politsei komissar Võrus 


\section{Mõned märked hra Nuderi poolt kokku seatud}

\section{Petserimaa olukorra kirjelduse kohta}

\section{S. Sommeri märkused tehtud minu palvel J.H.}

“Petserimaa olukorra kirjelduses” püütase enam vähem täielik ülevaade anda nimetatud maa praeguse seisukorra kohta ja ühtlasi ka teid näidata, kuidas neid puuduseid parandada tuleks. Nendest Petserimaa tervenduste kavadest on sagedasti ajakirjanduses ja tegelaste vahel juttu olnud teede parandamine, soode kuivendamine, Peipsi veepinna alandamine, ühistegevuste edendamine, hariduse arendamine, riigimeelsuse kasvatamine, töö muretsemine, kohati rahvaarvu harvendamine, põllukultuuri tõstmine jne. Kuid eelpool nimetatud kirjelduses on nad tervikuna käsitatud ja vastavalt põhjendatud. Kuid kirjelduses vahetevahel selgub, et autoril mitmegi küsimuse üle täpsemad teated puuduvad. Nii soovitakse $17 \mathrm{lk}$. Petserimaal laenuhoiuühisusi asutada, kuid nimetatud ühisuste võrk on juba täielik ja iga uus rahaasutus oleks üleliigne. Ka piimatalituste kohta on samas või ebaõiged andmeid käsitatud. Praegu on piimaühisused Meremäe, Mäe, Vilo ja Rootova valdades kokku 6 iseseisvat ühisust ja koorejaama kavas on igasse valda alata ühispiimatalitus.

Lhk. 18 soovitakse korraldada käsitöö ja majapidamise alal kursused, kuid nimetatud kursused on 3 aastat järgemööda Petserimaal tegutsenud ja töötavad ka praegu. Muidugi on neid tarvis ka tulevikus korraldada.

25 lhk. kurdab autor riikliku propaganda puuduse üle nagu oleks seda ainult valimiste alal üksikute poliitiliste rühma agitaatorite poolt tehtud. See võib ainult õige olla Vene poolt kodanikkude kohta, kuid setude seas on üle tuhande rahvakoosoleku suuremast osast Piirimaade Seltsi poolt korraldatud, kus peale muude küsimuste on jutt suurt rõhku riikliku propaganda peale pandud: Piirimaade Seltsi on ka 3 aastat järgemööda ühes N. Liiduga Petserimaal majapidamise, käsitöö, kudumise ja osalt aia- ja põllutöökursuseid peetud.

Lhk. 17 soovitab hra. Nuder, et Petserimaa ühistegevuseks ja algatamiseks puuduvad jõud ja peaksivad kusagilt sisemaa ühistegelised asutused oma osakonnad seal avama. Kuid see on täiesti põhjendamata arvamine. Petserimaal on ühistegeliste asutuste arv viimasel ajal kaunis kiiresti kasvamas. Laenuhoiuühisusi on tervelt 15 , piimaühisusi 6 , kalurite ühinguid ligi 10. Mitmed uued ühisused on asumas. Iseseisvad ühisused kasvatavad tegelasi ja võidavad rohkem poolehoidu kui sisemaa ühisuste osakonnad. 
Need on üksikud puudused ja neid leidub veelgi, kuid saab sellestki. Need ei ole kuigi tähtsad. Kui Vabariigi Valitsus kavatseb lähemas tulevikus Petserimaal uuendusi ette võtta, siis võib hra. Nuderi poolt antud näpunäiteid arvesse võtta.

Mina omalt poolt tahaksin hra. Nuderi Petserimaa tervendamise kavale veel mõned juurde lisada, mis seal puuduvad:

Petserimaa elab praegu majanduslikult raskeid aegu üle, mis peaasjalikult tingitud on maareformist - küladelt kruntidele asumisest, mis suurte rahaliste kuludega on seotud. Seda loomulikku majanduslikku kitsikust suurendab märksa läinud aastal linahinna langemine üle poole endisest ja üldse viljakuse poolest kehva aasta. Endiste aastate linahindadega arvestades tehti kevadel laenu vekslite peale, kuid linahindade langemine pani laenuvõtjad raskesse seisukorda, mida külakurnajad kõrget protsenti võttes ära kasutasid. Et liiakasuvõtjate käest rahvast ära hoida, on tarvilik et nad kohalikkudelt laenuhoiuühistutelt hariliku turu protsendiga laenu saaksid. Selles mõttes ongi Petserimaal igasse valda laenuhoiuühisusi asutatud. Kuid nimetatud ühisused on veel noored ja oma kapitali neil vähe. Tarvilik oleks, et Eesti Pank neile rohkem krediiti usaldaks, kui seda siiamaani on olnud. Laenuhoiuühisustele antud krediit ei kergenda meilt üksnes laenusaamist, mis majanduslik elu tervendab, vaid võidab ka lugupidamist riigi vastu ja tervendab poliitilist meeleolu. Käesoleva aasta algul Eesti Pangast antud 2100000 krediit Petserimaa laenuhoiuühisustele on väga häid tagajärgesid andnud: hoiusummad ja ühisuste liimete arv on ligi poole suurenenud. Krediiti tuleks uuesti suurendada laenuhoiuühisustele, millel majandusliku elu tervendamiseks Petserimaal esimese järgu tähtsus oleks ja mis riigile midagi maksma ei läheks, vaid protsendi näol raha tooks.

Esimese järgutähtsusega on setude seas Eesti rahvusliku iseteadvuse õhutamine ja kasvatamine, et setud tunneksid endid Eesti rahva lahutamatu osana. See on riiklikult ja rahvuslikult tarvilik. Hoolitsetagu venelaste eest kui palju tahes, nemad jäävad meile ikkagi võõraks - vaatavad üle traataia ja unistavad oma suure isamaa üle.

Kuid setudel on küll rahvuslik kool ja vald, aga kirikutes kahjuks peetakse veel vene keeles jumalateenistust. 12 setu kogudust on ainuüksi puhtrahvuslikud, kuna 4 kogudust peetakse vene ja eesti keeles ning 7 koguduses ainult vene keeles jumalateenistust. Kirik on praegu setude seas venestamise abinõuks. Tuleks eeskätt Petserimaa setu kogudused rahvuslikel alustel korraldada ja Vene mõjule jäädavalt seal lõpp teha. See reform on küll teatavate kuludega seotud - tuleb uus kirik setudel ehitada - kuid sellest kulust peame üle saama. Setu rahvusliste koguduste reform peab ennem olema läbi viidud, kui venelased hakkavad oma autonoomiat teostama. 
Kiriku mõjul nõuavad praegu setud ka koolis vene keele õpetamist, sest lapsed kui suureks kasvavad ei saavat kirikus jumalateenistustel aru, mis vene keeles peetakse.

Ulakuse vastu võitlemiseks (kaklused ja pussitamised) soovitab hra. Nuder karistuse normide suurendamist, mis ka tarvilik oleks, kuid selleks aitaks ka politsei poolt hoolsam ja karmim tegutsemine palju kaasa. Varasemalt kui politsei eesotsas olid kindlama käega mehed, tuli ka ulakust ja Vene piirilt spionaaži suhtes ülekäimist vähem ette.

Valitsusel tuleks oma otsuste juurde, mis Petserimaa kohta tehakse, kindlasti jääda ja neid mitte nii kergesti muuta (Svaneri maalt väljasaatmise otsuse enneaegne muutmine). See tõstaks valitsuse prestiiži rahva silmas.

Kõigi uuenduste rutemaks ja kindlamaks läbiviimiseks tuleks Petserimaal ajutiseks maaülema koht ellu kutsuda.

\section{AвSTRACт: Report on the political and social situation in Petseri County in 1927}

The issue of Petseri County is still an important element of national continuity. The Tartu Peace Treaty transferred the rural municipalities of the Petseri region, which had previously belonged to the Governorate of Pskov, to the administration of the Republic of Estonia. This severed relations with eastern regions from the period of the Russian Empire. This detour brought rapid impoverishment in some communities, giving rise to a series of social problems in the region such as unemployment, alcoholism, etc. That is why anti-state sentiments emerged in the interwar period, primarily in the eastern part of Petseri County, which was populated mainly by Russian citizens whose interests were more closely linked to Russia's interior regions. Pro-Soviet political forces exploited such sentiments.

The published report is part of the Ministry of Internal Affairs archival collection (National Archives, RA, ERA.14.1.1395). It was drawn up in 1927 by Assistant Commissioner of the Political Police Nikolai Nuder at the request of Minister of Internal Affairs Jaan Hünerson. The reason for writing the report was the government's aim to re-establish the position of 
Petseri County Commander, which had existed in the first years of independence, in order to supervise local institutions and to bind Petseri more closely with the Estonian state. S. Sommer's comment on the report has been identified at the end of the publication. The value of the source lies in its relatively wide-ranging problematics, reflecting a clash of political and social, national and community interests in the region. In addition to the problems described, the report proposes possible solutions, yet without presenting more specific action plans. The document's focus is on the eastern regions of Petseri County in particular, demonstrating the region's weaker coherence with other Estonian territories. In addition to political and social aspects, the source also draws attention to man and the changing environment around him. In this case, rapid population growth and the paludification of areas along Lake Pskov led to a decrease in people's living space in the region. 